(C2019, Elsevier. Licensed under the Creative Commons Attribution-NonCommercialNoDerivatives 4.0 International http://creativecommons.org/about/downloads

cc) $(1) \Theta$ 


\title{
The Determinants of Companies' Levels of Integration: Does One Size Fit All?
}

\author{
Cristiano Busco \\ Roehampton Business School, University of Roehampton, SW15 5SL, London, UK \\ Department of Business and Management, LUISS Guido Carli, 00198, Rome, Italy \\ Cristiano.Busco@roehampton.ac.uk \\ Irma Malafronte* \\ Roehampton Business School, University of Roehampton, SW15 5SL, London, UK \\ Irma.Malafronte@ roehampton.ac.uk \\ John Pereira \\ Kingston Business School, Kingston University, KT2 7LB, London, United Kingdom \\ J.Pereira@kingston.ac.uk

\begin{abstract}
Maria Grazia Starita
Department of Business Studies and Quantitative Methods, University of Naples Parthenope, 80132, Naples, Italy

starita@uniparthenope.it
\end{abstract}

* Corresponding Author. Corresponding Address: Southlands College, 80 Roehampton Lane, Roehampton Business School, University of Roehampton, SW15 5SL, London, UK.

E. irma.malafronte@ roehampton.ac.uk T. +44 (0)20 83923801 


\title{
The Determinants of Companies' Levels of Integration: Does One Size Fit All?
}

\begin{abstract}
This article extends current knowledge in the field of integrated thinking and reporting (ITR) by providing new empirical evidence on the nature and determinants of companies' levels of integration (i.e. ITR levels). Based on legitimacy theory and stakeholder theory, we empirically investigate companies' levels of integration and examine the drivers of different ITR levels. Our results suggest that companies' levels of ITR, namely Holistic, Integrated, Conservative, and Minimalist, are related to company characteristics and tend to remain consistent over time exhibiting routine and imitation. Companies with greater size, leverage, bigger board size and meetings, as well as companies operating in sensitive industries and with higher environmental performance are more likely to exhibit a Holistic or Integrated level of integration, while Minimalist and Conservative levels are driven by the same variables in opposite direction. Furthermore, at country level, economic growth, market performance, citizens freedom and lower environmental performance significantly contribute to higher integration. These results could drive companies' choices alongside policymakers' initiatives, by identifying which levers should be pulled to achieve the desired level of integration, and suggest the need for a tailored approach rather than a one size fits all within the debate on the future developments of ITR.
\end{abstract}

Keywords Integrated thinking; Integrated reporting; Legitimacy theory; Stakeholder theory

Jel Codes M14; M49; G30 


\section{Introduction}

Corporate reporting represents the essential tool through which companies communicate with their stakeholders as part of their accountability and stewardship obligations (Fedération des Experts Comptables Européens, 2015; PwC, 2015). Recent trends in the broader business environment including globalisation, financial crisis, and changes in regulation - have increased stakeholders' expectations on corporate reporting and communication. Indeed, stakeholders are calling for enhanced reporting of corporate responsibility and other information that would impact business performance (Miller \& Skinner, 2015; PwC, 2013, 2015). In response to these growing needs, the ways organizations report their annual performances are currently being questioned, debated, and redesigned throughout the world, and the use of voluntary information is increasing to ensure transparency, accountability, and access to useful information (Busco, Granà, \& Quattrone, 2017; Dumay, Bernardi, Guthrie, \& Demartini, 2016).

In this context, Integrated Reporting (IR) is promoted as a solution to the concerns of financial reporting and has been portrayed by an emerging body of literature as in transition to make the leap from a promising concept to a powerful practice (Adams \& Simnett, 2011; Busco, Frigo, Quattrone, \& Riccaboni, 2013; Eccles \& Krzus, 2010). Whether presented as a rational choice to face existing challenges (Adams, 2015; Churet \& Eccles, 2014; Knauer \& Serafeim, 2014; Serafeim, 2015), as a ceremonial response to the increasing pressures of markets and society (Higgins, Stubbs, \& Love, 2014; van Bommel, 2014), or a temporary fad and fashion (Brown \& Dillard, 2014; Flower, 2015; Milne \& Gray, 2013), IR has rapidly gained considerable prominence as one of the main management and accounting innovations of the recent decade (Dumay et al., 2016; De Villiers, Rinaldi, \& Unerman, 2014; De Villiers, Venter, \& Hsiao, 2017a). IR is the visible part to external stakeholders of what is happening inside a business, i.e. integrated thinking (IT) and integrated decision-making (IIRC, 2013). To successfully incorporate IR in an organization, it needs to permeate all layers through IT, that is the active consideration by an organization of the relationships between its various operating and functional units and the capitals that the organization uses or affects (IIRC, 2013).

A growing number of studies investigate integrated thinking and reporting (ITR) practices. Early studies have focused on theoretical analyses (e.g., Adams, 2015; Eccles \& Krzus, 2010; Flower, 2015; Haller \& Van Staden, 2014) and case studies (e.g., Adams, Potter, Singh, \& York, 2016; Eccles \& Serafeim, 2014). Part of literature shows the adoption of IR to be associated with enhancing corporate reputation, attracting institutional investors, engaging stakeholders, and improving resource allocation (Burke \& Clark, 2016; Churet \& Eccles, 2014; Serafeim, 2015), while other literature questions the notion of IR as a superior reporting mechanism (Maniora, 2015). Few recent empirical studies analyse IR determinants and find growth opportunities, company size, gender diversity, profitability, industry concentration (Frías-Aceituno, Rodríguez-Ariza, \& García-Sánchez, 2013, 
2014), and country-level factors (Vaz, Fernandez-Feijoo, \& Ruiz, 2016) to explain the decision to present an integrated report. Recent studies published in the special issues of Accounting, Auditing and Accountability Journal in 2018 and Meditari Accountancy Research in 2017 provide micro-level analysis of IR and IT practices. However, more empirical evidence on ITR is crucial to inspire regulatory initiatives towards possible future mandatory IR requirements (Dumay et al., 2016). What seems to be missing, to the best of our knowledge, are empirical studies on the level of integration of financial and non-financial aspects in a firm's day to day decision making processes, how it evolves over time and its determinants. Indeed, companies can adopt different levels of integration, as management's commitment towards integration can happen at different levels. Recognising the existence of different levels of integration, analysing their distinctive features and determinants have the potential to inspire IR development towards either ad hoc initiatives or a one size fits all approach.

Aiming to address this gap, this paper relies on a sample of 583 European listed companies over the period 2002-2015 to achieve a threefold purpose. First, we identify companies' levels of integration and observe their evolution over time to address the first research question: i) What are companies' levels of integration? We define the level of integration (or ITR level) focusing on a measure of management's commitment and effectiveness towards integrating financial and extrafinancial aspects, retrieved from Thomson Reuters Asset4 database, thus differentiating from previous literature that investigates IR based on whether or not companies issue an integrated report (Frías-Aceituno et al., 2013, 2014; Vaz et al., 2016). Second, we investigate whether and how the different integration levels are related to companies' idiosyncratic characteristics to answer our second research question: ii) Are integration levels related to companies' characteristics? We identify four different integration levels (or ITR levels, i.e. Holistic, Integrated, Conservative, and Minimalist) by grouping companies based on the distribution of their integration levels over time (see Section 4.1). Finally, we investigate the determinants of the different integration levels building on legitimacy theory and stakeholder theory; we empirically test whether a company's level of integration is the result of a legitimation process, especially for bigger and more profitable companies (i.e. De Villiers \& van Staden, 2006; O’Donovan, 2002), as well as whether it represents a way to account towards stakeholders, specifically through corporate governance (i.e. Freeman, 2010; FríasAceituno et al., 2013). For this purpose, we implement panel data models to address our third research question: iii) What drives companies' levels of integration?

The main results show that companies' different levels of integration (i.e. ITR levels) are related to their idiosyncratic characteristics and tend to be consistent over time exhibiting routine and imitation. Each level expresses a company's commitment towards the integration of financial and non-financial aspects, that is higher for Holistic companies, followed by Integrated, Conservative, and finally lowest for Minimalist companies. The analysis of companies' levels of integration, 
together with their characteristics (i.e. performance, size, risk, governance, and sector) lead to the presentation of four comprehensive groups and allow observing the evolution over time. Furthermore, the analysis of the determinants of ITR levels documents that the level of integration is not a random choice as it depends on companies' characteristics. Companies with greater size, leverage, bigger board size and meetings, as well as companies operating in sensitive industries and with higher environmental performance are more likely to exhibit higher levels of integration (Holistic or Integrated). Similarly, firms operating in countries with higher level of economic growth, market performance, citizens freedom, and lower environmental performance are more likely to be Holistic or Integrated. Lower level of integration (Minimalist or Conservative) is driven by the same key variables but in the opposite direction. These findings show clear differences in the level of integration based on companies' size; large firms are in a better position to do integrated thinking and reporting as they have the required resources and they can make all the efforts to bring integration within the organization; on the other side, small firms simply don't do it because they seem not to have the necessary resources, capacity, maybe incentives, to be more integrated. These results recommend the need for a tailored approach, rather than a one size fits all, towards possible adoption of ITR that takes into consideration company specific characteristics. These outcomes are confirmed across a variety of robustness checks.

This research complements the existing literature on corporate reporting by providing new empirical evidence on ITR level and its determinants, thereby answering the call for further empirical evidence in this field (Adams, 2015; De Villiers et al., 2017a; Dumay et al., 2016; Serafeim, 2015). We contribute to previous literature on corporate reporting (among others, Cheng, Ioannou, \& Serafeim, 2014; Luo, Wang, Raithel, \& Zheng, 2015; Qiu, Shaukat, \& Tharyan, 2016) by identifying distinctive ITR levels and their evolution over time. We complement previous studies on the determinants of IR (Frías-Aceituno et al., 2013, 2014; García-Sánchez, Rodríguez-Ariza, \& FríasAceituno, 2013; Jensen \& Berg, 2012; Vaz et al., 2016) by using an alternative measure and a comprehensive dataset, and we expand the analysis of ITR determinants across distinctive ITR levels. Furthermore, by providing an in depth empirical analysis on ITR levels and the role of companies' characteristics in affecting these levels, this study contributes to the debate on the future developments of IR by offering insights to companies and policymakers about which levers should be pulled to achieve the desired level of integration, and highlighting the need for a tailored approach. From a practical perspective, the findings from this study suggest companies are not all the same in their integration journey, indeed they can be substantially different, and these differences need to be carefully considered across different perspectives. An improved understanding of the predispositions towards integration is of interest to managers, because they would be interested in identifying which internal levers can be pulled to enhance integration as well as how the external environment affect 
this; to regulators, because they may want to consider implementing regulations that should be differentiated based on companies' characteristics and the environment in which they operate; to policymakers, i.e. IIRC, because our findings may support initiatives related to the creation of special interest groups studying IR and IT best practices based on companies size, performance, and sector; to capital market participants, because these findings can inform their investment decision making.

The remainder of the paper is organised as follows. Section 2 reviews the literature, discusses the theoretical framework, and develops the hypotheses to test. Section 3 describes sample, variables, and empirical models. Section 4 provides the empirical results. Section 5 concludes the paper. 


\section{Literature Review}

\subsection{Integrated Thinking and Reporting: Current Knowledge and Research Gap}

The International Integrated Reporting Council (IIRC) defines IR as a process founded on IT that results in a periodic integrated report, which is "a concise communication about how an organization's strategy, governance, performance and prospects, in the context of its external environment, lead to the creation of value over the short, medium and long term" (IIRC, 2013, p. 7). Through IR, top management communicates, mainly to investors, how sustainability issues and initiatives are expected to contribute to the business growth in the short, medium, and long-term (Churet \& Eccles, 2014; IIRC, 2013). As described by IIRC (2013), IT is the active consideration of the relationship between a company's operating units and the capitals; IT leads to integrated decisionmaking and actions towards value creation over the short, medium, and long term. Overall, the number of companies implementing IR and providing specific examples in their annual reports is small but increasing; its structure is evolving from a sustainability reporting focus to a purely business and investor focus (Milne \& Gray, 2013) and its implementation requires a change in accounting and management processes within the organization (Adams, 2015). So far, apart from companies listed in the Johannesburg Stock Exchange (King IV, 2016), IR represents a voluntary disclosure in other countries where companies can consider adopting a principle-based framework as proposed by IIRC (2013).

Academic literature shows a growing interest in the field although an extensive review conducted by Dumay et al. (2016) documents little research examining ITR practices. Majority of studies focus on theoretical analyses (e.g., Adams, 2015; Eccles \& Krzus, 2010; Flower, 2015; Haller \& Van Staden, 2014) and case studies (e.g., Adams et al., 2016; Eccles \& Serafeim, 2014). While an extensive literature investigates the determinants of corporate social and environmental reporting, few recent empirical studies examine the factors that may influence managers' actions towards IR (e.g., Frías-Aceituno et al., 2013, 2014; García-Sánchez et al., 2013; Jensen \& Berg, 2012; Vaz et al., 2016). A stream of literature documents several benefits arising from companies' commitment towards IR: IR has a positive association with quality of management (Churet \& Eccles, 2014); IR advances corporate reputation resulting in a better ability to attract institutional investors (Serafeim, 2015; Steyn, 2014); IR improves external engagement with stakeholders by reducing information asymmetry, and leads to better resource allocation, cost reduction, and better alignment between internal and external reporting (Burke \& Clark, 2016). Similarly, Brown and Dillard (2014) highlight the role of IR as a new way to explain how a company creates value over time, and Bernardi and Stark (2016) show the effectiveness of IR on analyst forecast accuracy in South Africa. Adams et al. (2016) document that companies committed to the IIRC pilot programme present more clear 
disclosure on the purpose and outcomes of social investment and its link to long-term progress, risk, and strategy. Maniora (2015) instead contradicts the general notion of IR as a superior reporting mechanism as the benefits of IR are driven by several factors and depend on the sample group observed. Along the same lines, Reimsbach, Hahn, and Gürtürk (2017) find that integrating sustainability and financial information increases access but does not improve acquisition of sustainability information. Recent research also attempts to develop an initial framework for the assurance of an integrated report (Maroun, 2017).

The special issue of Meditari Accountancy Research (2017) contributes to explain IR processes and practices. De Villiers, Hsiao, and Maroun (2017b) present a conceptual model of the overall IR process that can be used as an organising framework to understand about various influences, identify factors to control for in a study, and find previously unexplored research questions. Their model is based on IR literature and includes IR determinants and consequences, acknowledges IIRC's processes and influences, and shows report users and preparers. Although the model shows the main cause and effect relationships (i.e. organizational factors can affect the adoption of IR), the authors acknowledge the possibility of reverse causality, as well as concepts within each group can influence each other. While McNally, Cerbone, and Maroun (2017) explore challenges and highlight practical issues of producing an integrated report, Dumay, Bernardi, Guthrie and La Torre (2017) focus on barriers and issues in the IIRC framework that has hindered a wider adoption and implementation of IR. Drawing on an interpretation of materiality as a social construction, Lai, Melloni, and Stacchezzini (2017) explore the meaning that practitioners attach to the IR principle by focusing on who participates in determining IR materiality. Du Toit (2017) investigates the readability of integrated reports to determine whether they are accessible to their readership and if they add value to stakeholders. Del Baldo (2017) discusses the usability of the IIRC framework for small and medium-sized enterprise (SME) and the need to adapt the IR principles to SME needs and features. Dumay and Dai (2017) explore integrated thinking as a cultural control and present the case study of a small Australian bank. Guthrie, Manes-Rossi, and Orelli (2017) analyse changes in internal structures and processes following the introduction of the IR framework, finding that the adoption of the framework has led to IT, however the change is more incremental than revolutionary. The special issue also includes case studies across different countries, i.e. South Africa (Du Toit, 2017; McNally et al., 2017), Australia (Dumay \& Dai, 2017), Columbia (Macias \& Farfan-Lievano, 2017) and Italy (Silvestri, Veltri, Venturelli, \& Petruzzelli, 2017).

Based on the analysis of 65 published IR research studies over the period 2012-2017 and using the idea journey theoretical framework, Rinaldi, Unerman, and De Villiers (2018) conceptualize and analyse the development of IR as an "idea journey" to highlight challenges, success, strengths and weaknesses that IR experiences across the whole of its journey. The idea journey comprises a 
sequence of five main phases (i.e. idea generation, idea elaboration, idea championing, idea production, and idea impact) and previous studies are classified over these five main phases. This research documents a considerable growth in volume and scope of research studies, although it emerges that IR research has not yet covered the entire IR journey; indeed, there is relatively little IR research at the final journey phase of idea impact. Some of these gaps have been filled by recent papers, published in the special issue of Accounting Auditing and Accountability Journal (2018), that provide micro-level analysis of IR practices at the idea impact phase of the IR journey. McNally \& Maroun (2018) show that the decision to prepare an integrated report in an African eco-tourism company has led to different forms of resistance to the introduction of IR and IT which can limit its change potential; nonetheless, accounting for financial and non-financial information through IR has a transformative potential which may lead to broader management control and a more integrated conception of value. IR is envisioned as a "rational myth" in a multinational European company, that challenged the vision of IR suggested by IIRC and implemented its own version of an integrated company (Gibassier, Rodrigue, \& Arjaliès, 2018). Lai, Melloni, and Stacchezzini (2018) find that, for an insurance company, IR stimulates deep reasoning processes and facilitates dialogue between preparers and users; IR provided an opportunity to face challenges inherent to the insurance sector; although IR is able to produce socializing effects for a range of stakeholders, investors and financial stakeholders represent the primary addressees of IR. The analysis conducted by Vesty, Ren, and Ji (2018) document how the position of an individual senior manager can indicate to other in the organization whether to support the implementation of the IR idea. Al-Htaybat and von AlbertiAlhtaybat (2018) describe the mechanisms that led a global service company to be an integrated thinker and document that IT comes first, is managed from the top, and IR represents its natural extension in the case of a global service company.

Although ITR research is emerging in the financial reporting literature, to the best of our knowledge there is no empirical evidence on companies' levels of integration. Indeed, in the context of voluntary disclosure, companies can choose different degrees of integration of financial and nonfinancial aspects in their decision-making processes, thus resulting into different levels of integration in thinking and reporting (i.e. ITR level). Observing companies' voluntary behaviour towards ITR and identifying the determinants would be crucial to drive companies' choices alongside policy initiatives within the corporate reporting debate. Specifically, if companies' level of integration is related to their idiosyncratic characteristics, it would suggest the need for tailoring corporate voluntary reporting practises, rather than assuming a one size fits all approach. 


\subsection{Theoretical Background}

Socio-political theories, including legitimacy theory and stakeholder theory, have been extensively used by previous literature to investigate corporate reporting practices, and in particular sustainability reporting (Comyns, 2016; Prado-Lorenzo \& García-Sánchez, 2010; Qiu et al., 2016; Reverte, 2009).

Legitimacy theory considers the relationship between the organization and society (Comyns, 2016) and is based on the idea that, in order to continue to operate successfully, corporations must act within the bounds of what society identifies as socially acceptable behaviour (O'Donovan, 2002). To remain legitimate, companies may conform or attempt to alter social perceptions and expectations; if any change is agreed, this must be accompanied by disclosures, so that the intended audience is informed about what the company is doing as part of the legitimation process (Dowling \& Pfeffer, 1975; O'Donovan, 2002). Legitimacy theory assumes the existence of a social contract between the business and the individual members of the society, based on which every company has a moral obligation to act in a socially responsible manner (Guthrie \& Parker, 1989; O’Donovan, 2002). Consequently, corporate disclosures are made as reactions to environmental factors, are driven by public pressure, and aim to achieve social legitimacy, particularly for companies having a significant environmental and social impact (Campbell, 2000; Cho \& Patten, 2007; Gray, Kouhy, \& Lavers, 1995; Guthrie \& Parker, 1989; Hackston \& Milne, 1996; Patten, 1991, 2002; Walden \& Schwartz, 1997). Indeed, companies may use disclosures, or increase the extent of their disclosure, when they feel their legitimacy is threatened, i.e. following negative events or external pressure (Branco, Eugénio, \& Ribeiro, 2008; Comyns, 2016). Legitimacy theory is useful in explaining the role of company size and profitability in affecting the level of integration; we want to empirically test whether a company's level of integration is the result of a legitimation process, especially for bigger and more profitable companies (i.e. De Villiers \& van Staden, 2006; O'Donovan, 2002). Indeed, bigger and more profitable companies are in the spotlight of public opinion, receive public pressure, have more resources, and, therefore, are expected to be more inclined to have higher integration levels and to show their integration to remain legitimate.

While legitimacy theory focuses on the relationship between the organization and society, stakeholder theory refers to the relationship between the organization and its stakeholders (Comyns, 2016). Freeman $(1984$, p.46) defines a stakeholder as "any group or individual who can affect or is affected by the achievement of the firm's objectives". According to stakeholder theory, a major objective of the firm is to balance the conflicting demands of various stakeholders (Ansoff, 1965; Donaldson \& Preston, 1995) as well as a major role of corporate management is to assess the importance of meeting stakeholder demands to achieve firms' strategic objectives (Freeman, 2010). As such, stakeholder theory has been used in previous studies to explain social responsibility disclosure (Depoers, Jeanjean, \& Jérôme, 2016; Donaldson \& Preston, 1995; Freeman, 2010; Frías- 
Aceituno et al., 2013; Roberts, 1992; Ullmann, 1985). Companies use environmental and social reporting to account for their activity towards stakeholders, i.e. shareholders, creditors, legislative bodies, customers, suppliers, and special interest groups (Freeman, 2010; Frías-Aceituno et al., 2013; Roberts, 1992). Similarly, stakeholder theory is useful in explaining the link between governance characteristics and the level of integration; for example, the board of directors, as main decisionmaking body in an organization, is responsible for safeguarding the interests of the different stakeholders also by integrating relevant financial and non-financial information in the decision process as well as through the dissemination of information (Ferreira, 2010; Frías-Aceituno et al., 2013). We want to empirically test whether a company's level of integration represents a way to account towards stakeholders, specifically through corporate governance (i.e. Freeman, 2010; FríasAceituno et al., 2013).

\subsection{Hypotheses Development}

\subsubsection{Company size}

Previous literature finds size and industry classifications as main drivers of social disclosure (i.e., Cormier, Magnan, \& Van Velthoven, 2005; Cowen, Ferreri, \& Parker, 1987; Frías-Aceituno et al., 2013; Patten, 1991; Qiu et al., 2016). Larger companies tend to receive more attention from the general public and higher pressure to exhibit social responsibility (i.e. Cowen et al., 1987; Qiu et al., 2016), whereas smaller sized companies might not have the same level of public pressure and might tend to provide information through more informal channels (Cowen et al., 1987). Moreover, companies whose activities have the potential to affect the environment, i.e. those operating in consumer-oriented industries, can be expected to exhibit greater concern and enhanced social responsibility disclosure (Cowen et al., 1987). Legitimacy theory can help explain the relationship between firm size and the level of integration; indeed, corporations voluntarily disclose social and environmental information to send messages to "society" (Deegan, Rankin, \& Voght, 2000; O’Donovan \& Gibson, 2000), and their legitimation techniques/tactics would differ depending on whether the organization is trying to gain, or extend, or maintain legitimacy or to repair (or defend) its lost or threatened legitimacy (O'Donovan, 2002). Bigger corporations are more in the spotlight of public opinion, receive public pressure and, therefore, will do whatever they regard as necessary in order to preserve their image of a legitimate business (De Villiers \& van Staden, 2006). In the context of IR, Frías-Aceituno et al. (2014) find size, profitability, and industry concentration have a positive impact on producing an integrated report, rather than a financial report or a sustainability report. Similarly, García-Sánchez et al. (2013) find that larger and more profitable companies carry out 
wider-ranging disclosure practices, as well as firms in the capital goods and utilities sectors are more likely to publish an integrated report. Large companies are more visible to the public, more newsworthy and more likely to be subject to public resentment, consumer hostility and attention of regulatory bodies (Henderson, Peirson, Herbohn, \& Howieson, 2015; Reverte, 2009); consequently, they are expected to engage more in voluntary disclosures as legitimating behaviour (Dowling \& Pfeffer, 1975; Reverte, 2009). In line with these arguments and based on legitimacy theory, we expect that bigger companies are in the spotlight of public opinion and therefore are more inclined to operate and communicate in an integrated manner.

H1. Company size has a positive and significant impact on the level of integration.

\subsubsection{Profitability}

In the context of legitimacy theory, Neu, Warsame, and Pedwell (1998) assume the relationship between financial and environmental information can be either confirmatory or disconfirmatory, i.e. positive or negative. When the organization is profitable, environmental disclosure would reassure stakeholders that profit has not been made at the expense of the environment; whereas when the company is not profitable, environmental disclosure may instead convince stakeholders that the current environmental investments will lead to long-term profitability (Neu et al., 1998). A positive relationship between profitability and social disclosure can be explained by management's knowledge: if the management has the ability to make a company profitable, along the same lines it would be able to understand the importance of disclosing social and environmental information (Belkaoui \& Karpik, 1989). Moreover, profitable companies also have more resources available to support voluntary disclosures while companies with constrained resources may need to be selective in allocating resources on activities that impact their performance (Reverte, 2009). These arguments seem to suggest that higher profitability would lead to higher levels of integration. However, empirical evidence shows contrasting results (Cho \& Patten, 2007; Frías-Aceituno et al., 2014; García-Sánchez et al., 2013; Patten, 2002). Moreover, literature shows that corporations can decrease specific disclosures when they perceive them to be potentially more damaging than helpful to maintain legitimacy, thus adding the dimension of reduced disclosure as a legitimising strategy (De Villiers \& van Staden, 2006). Any change needs to be accompanied by disclosures (O'Donovan, 2002) and corporations may reduce environmental disclosures at some point or change the type (general/specific) of disclosure as and when they perceive shifts in legitimacy threats (De Villiers \& van Staden, 2006). Based on the existing debate, and drawing from legitimacy theory, we expect the existence of a significant relationship between profitability and the level of integration, but no assumption is made on the direction of the relationship.

H2. Company profitability has a significant impact on the level of integration. 


\subsubsection{Governance}

According to Jensen and Meckling (1976), the relationship between internal governance mechanisms and corporate disclosure practices may be complementary or substitutive. On the one hand, the complementary relationship assumes that effective corporate governance mechanisms will strengthen company's internal control; in an intense monitoring environment, the management is less likely to withhold information thus resulting in more information disclosed to reduce opportunistic behaviours and information asymmetry (Leftwich, Watts, \& Zimmerman, 1981). On the other hand, the relationship may be substitutive as the strength of corporate governance, and therefore the security and reliability of internal control mechanisms, would lead to reduced disclosure; in such situation, one corporate governance mechanism may substitute the other (Cheng \& Courtenay, 2006; Cormier \& Magnan, 2014; Samaha, Khlif, \& Hussainey, 2015). However, each corporate mechanism is not a panacea (Frías-Aceituno et al., 2013) and therefore it is desirable a complementary view with overlapping checks and balances. In this research we assume a complementary relationship and test the impact of corporate governance characteristics, i.e. board size, activity, and independence, on the level of integration. We follow stakeholder theory and the idea that companies need to be able to balance demands of various stakeholders, besides shareholders and creditors (Ansoff, 1965); there is a wide range of stakeholders who are interested in companies' attitudes towards sustainability, nonfinancial information and integration in day to day decision making processes (Frías-Aceituno et al., 2013). In light of stakeholder theory, we believe that corporate governance mechanisms, such as board size, activity, and independence, play an important role in defining good practices to enhance corporate disclosure, stakeholder engagement, as well as achieve holistic transparency and integration.

Previous studies find contradicting results for the relationship between board size and firm voluntary disclosure. On the one hand, large board size increases the pool of expertise and available resources (Hidalgo, García-Meca, \& Martínez, 2011), allow diverse experiences and opinions potentially increasing board's supervisory capacity, thus implying more voluntary disclosure (Gandía, 2008); greater board size and diversity is found to have a positive influence on the integration of corporate information (Frías-Aceituno et al., 2013). On the other hand, Herman (1981) argues that large boards are more likely to be ineffective as it is difficult to schedule meetings and reach consensus (Lipton \& Lorsh, 1992) reducing the board's monitoring ability and contributing to less voluntary information; on this line, Prado-Lorenzo and García-Sánchez (2010) document a negative relationship between board size and information disclosure on greenhouse gases, thus suggesting that board of directors are more focused on creating economic value, rather than dealing with social responsibility and stakeholders' expectations. Other studies (i.e. Arcay \& Vazquez, 2005; Cheng \& Courtenay, 2006; Karamanou \& Vafeas, 2005) find no significant relationship between size 
and voluntary disclosure. In the context of our research, we believe that the integration of financial and non-financial aspects in day to day decision-making requires the involvement of directors with sufficient experience and diversity, which is more common to have in larger boards. We expect that higher number of directors would lead to better monitoring and, consequently, this would have a positive effect on the breadth and integration of corporate reporting and decision-making process (Frías-Aceituno et al., 2013; García-Sánchez, Rodríguez Domínguez, \& Gallego Álvarez, 2011).

H3. Board size has a positive and significant impact on the level of integration.

Previous studies have used board meeting frequency to proxy for strategic control (Vafeas, 1999), board workload (Linck, Netter, \& Yang, 2008) or board vigilance in the presence of activist shareholders (Cohn \& Rajan, 2013). Board meetings are considered fundamental for directors to obtain information, participate in decision making, avoid personal liability, and perform their monitoring and advisory roles (Adams \& Ferreira, 2012). A stream of literature documents that more active boards result in better supervision and control, as well as have interest in providing higher disclosure to inform stakeholders about their efforts (Lipton \& Lorsch, 1992). Moreover, when boards have a considerable number of meetings, they are able to execute their supervisory functions more effectively, thus resulting in reduced information asymmetry (Frías-Aceituno et al., 2013; Kanagaretnam, Lobo, \& Whalen, 2007). Following from the stakeholder theory and in line with previous literature, we believe that a higher number of board meetings would have a positive impact on the level of voluntary disclosures and increase the level of integration of corporate reporting and decision-making process.

H4. Board meetings have a positive and significant impact on the level of integration.

The independence of the board of directors usually refers to the presence of non-executive directors and represents an essential corporate governance mechanism to control the actions of managers and protect stakeholders' interests (Fama \& Jensen, 1983; Frías-Aceituno et al., 2013). Non-executive directors are expected to apply greater objectivity and independence in their company management (Prado-Lorenzo \& García-Sánchez, 2010) and are most interested in ensuring regulation compliance and responsible behaviour (Zahra \& Stanton, 1988). This results in increased quality and quantity of information as well as the ability to be more receptive to new information demands (García Sánchez et al., 2011). Independent board members are expected to defend the dissemination of information as a way to ensure accountability (Prado-Lorenzo \& García-Sánchez, 2010) and, consequently, boards with higher percentage of independent directors are expected to have higher voluntary disclosures and commitment towards integration.

H5. Board independence has a positive and significant impact on the level of integration. 


\section{Methodology}

\subsection{Sample}

The sample for this study is drawn from the STOXX Europe 600 Index representing large, mid, and small capitalization companies across 18 European countries $^{1}$ for the period 2002-2015. Based on the availability of relevant data for this study, the final sample includes 583 companies for the period of analysis, that make up 6,318 firm-year observations. Table 1 presents the distribution of the sample across country in Panel A and across single-digit Industry Classification Benchmark (ICB) in Panel $\mathrm{B}^{2}$.

[Table 1 near here]

\subsection{Variables}

Table 2 describes the variables used in the analysis. Firm specific variables are sourced and built from Datastream and Thomson Reuters while macroeconomic variables are collected from Bloomberg, World Bank, and other sources ${ }^{3}$. The main variable of interest, ITR_SCORE, is collected from Thomson Reuters Asset4 database and measures "a company's management commitment and effectiveness towards the creation of an overarching vision and strategy integrating financial and extra-financial aspects", , thus reflecting a firm' ability to "convincingly show and communicate" the integration of both financial and non-financial dimensions in its day-to-day decision-making processes. Thomson Reuters Asset4 assigns this overall score based on data points collated on an annual frequency for each company. The individual company score is estimated by equally weighting and z-scoring all underlying data points and comparing them against all companies in the Asset4 universe using a proprietary system. In describing the score, Asset4 refers to drivers and outcomes (De Villiers et al., 2017a). The components of the score (see Appendix) capture whether integration is incorporated into managers' day to day decision making, i.e integrated thinking, as well as the ability to communicate, i.e. reporting outcomes. Thus, we consider ITR_SCORE as a relative measure of the level of integration, in both thinking and reporting (ITR level), for a firm in a year and is

\footnotetext{
${ }^{1}$ The STOXX Europe 600 Index, derived from the STOXX Europe Total Market Index (TMI), is a subset of the STOXX Global 1800 Index, and has a fixed number of 600 components. At the time of data collection (August 2016), STOXX Europe 600 Index included companies across 18 European countries: Austria, Belgium, Czech Republic, Denmark, Finland, France, Germany, Greece, Ireland, Italy, Luxembourg, the Netherlands, Norway, Portugal, Spain, Sweden, Switzerland, and the United Kingdom. Since $19^{\text {th }}$ September 2016, Greece was removed from this Index, following its re-classification as emerging and developing market.

${ }^{2}$ The sample includes both financial and non-financial companies. In the context of ITR, financial companies do not follow different set of frameworks (i.e. International Integrated Reporting Framework by IIRC, 2013); therefore, financial companies are not excluded from the sample. In support of this, the ITR_SCORE variable used in the analysis, as measured by Datastream, applies the same criteria for all companies across different sectors. However, robustness checks are provided to test the existence of specific ITR strategies for firms operating in non-financial sectors (Section 4.4).

${ }^{3}$ Yale Center for Environmental Law and Policy; Reporters Without Borders.

${ }^{4}$ As described in Thomson Reuters Asset4 database.
} 
expressed as a percentage between 0 (minimum level) and 100 (maximum level). Based on the distribution of ITR_SCORE each year over 2002-2015, we categorise firms as adopting four levels of ITR (i.e. Holistic, Integrated, Conservative, and Minimalist ${ }^{5}$. While relatively widespread in the corporate reporting literature (i.e., Cheng et al., 2014; Luo et al., 2015; Qiu et al., 2016), Thomson Reuters Asset4 scores have also been used in recent studies in the field of IT and IR (i.e. Maniora, 2015; Serafeim, 2015; Venter, Stiglingh, \& Smit, 2016). See Table 2 for a description of the variables and the appendix for further details on ITR_SCORE.

[Table 2 near here]

\subsection{Empirical Models}

The empirical analysis aims to investigate the drivers of different levels of integration. Using univariate analysis on a range of firm fundamentals, we identify four ITR groups and explore their switching behaviour over time. This initial analysis is crucial to investigate whether each ITR group is significantly different from the others as well as whether and how a company's level of integration changes over time.

Panel data regressions are then used to test the research hypotheses ${ }^{6}$. First, we estimate a panel data random effect regression model (Eq.1) to investigate the impact of company characteristics on the level of integration.

$$
\begin{aligned}
& \text { ITR_SCORE }_{i, t}=\alpha+\beta_{1} \operatorname{SIZE}_{i, t-1}+\beta_{2} \text { ROE }_{i, t-1}+\beta_{3} \text { BOARD_SIZE }_{i, t-1}+\beta_{4} \text { BOARD_MEET }_{i, t-1}+ \\
& +\beta_{5} \text { BOARD_INDEPEND } D_{i, t-1}+\sum_{j} \beta_{j} \text { FIRM_CONTROL }_{j, i, t-1}+\sum_{h} \beta_{h} \text { COUNTRY_CONTROL }_{h, t}+\varepsilon
\end{aligned}
$$

The dependent variable in Eq. (1) is the integrated thinking and reporting score (ITR_SCORE). It is a function of firm size $\left(S I Z E-H_{1}\right)$, profitability $\left(R O E-H_{2}\right)$, and governance variables $\left(B O A R D \_S I Z E-H_{3}, B O A R D \_M E E T-H_{4}, B O A R D \_I N D E P E N D-H_{5}\right) ; i(i=1,2, \ldots, 583)$ identifies the sample companies and $t$ represents the period $(t=2002,2003, \ldots, 2015)$. We also control for other firm characteristics, including LEVERAGE, STRATEGIC_SHARE, CEO_SHARE, ENV_PERF, IND_SENS (following De Villiers et al., 2017a; De Villiers \& Marques, 2016; De Villiers, Naiker, Van Staden, 2011; Frías-Aceituno et al., 2013, 2014; García-Sanchez et al., 2013; Qiu et al., 2016) ${ }^{7}$. Moreover, we use country level variables to control for country's economy (GDP), stock market (MARKET_INDEX), environmental impact (EPI_INDEX), investor protection (INV_PROT), World Bank measures (VOICE_ACC_WB, REG_QUAL_WB, $G O V_{-} E F F_{-} W B$ ) and media freedom

\footnotetext{
${ }^{5}$ The empirical analysis for the identification of the different ITR levels is detailed in Section 4.

${ }^{6}$ We test for random effect model using the Breusch-Pagan Lagrange multiplier test. The null hypothesis $\left(\mathrm{H}_{0}\right.$ : The variance across entities is zero) is rejected in favour of the panel effect for the sample. The statistics are not reported here and available on request.

${ }^{7}$ One period lag of firm specific characteristics and governance variables allows controlling for endogeneity in the regression model.
} 
(FREEDOM) following previous literature (i.e. De Villiers et al., 2017a; De Villiers \& Marques, 2016; Jensen \& Berg, 2012; Simnett, Vanstraelen, Chua, 2009; Vaz et al., 2016). See Table 2 for variables description. To validate the results, the dependent variable from Eq.(1) is replaced by a categorical variable representing the four ITR levels, and an ordered logistic panel data regression model is implemented to further investigate the role of company characteristics in affecting the different ITR levels.

Furthermore, in order to capture more complicated relationship, we discretize the ITR_SCORE into ITR categories and logistic panel data random effect regressions are used to estimate the factors affecting the probability of belonging to a specific ITR group with respect to the others, as follows:

$$
\begin{aligned}
& \operatorname{Pr}\left(\text { HOLISTIC }_{i t}=1\right)=f\left(\beta_{1} \text { SIZE }_{i, t-1}+\beta_{2} \text { ROE }_{i, t-1}+\beta_{3} \text { BOARD_SIZE } E_{i, t-1}+\beta_{4} B O A R D \_M E E T_{i, t-1}+\right. \\
& \left.+\beta_{5} \text { BOARD_INDEPEND }_{i, t-1}+\sum_{j} \beta_{j} \text { FIRM_CONTROL }_{j, i, t-1}+\sum_{h} \beta_{h} \text { COUNTRY_CONTROL }_{h, t}\right) \\
& \operatorname{Pr}\left(\operatorname{INTEGRATED}_{i t}=1\right)=f\left(\beta_{1} \text { SIZE }_{i, t-1}+\beta_{2} \text { ROE }_{i, t-1}+\beta_{3} \text { BOARD_SIZE }_{i, t-1}+\beta_{4} \text { BOARD_MEET }_{i, t-1}+\right. \\
& \left.+\beta_{5} \text { BOARD_INDEPEND }_{i, t-1}+\sum_{j} \beta_{j} \text { FIRM_CONTROL }_{j, i, t-1}+\sum_{h} \beta_{h} \text { COUNTRY_CONTROL }_{h, t}\right) \\
& \operatorname{Pr}\left(\text { CONSERVATIVE }_{i t}=1\right)=f\left(\beta_{1} \text { SIZE }_{i, t-1}+\beta_{2} R O E_{i, t-1}+\beta_{3} \text { BOARD_SIZE }_{i, t-1}+\beta_{4} B O A R D \_M E E T_{i, t-1}+\right. \\
& \left.+\beta_{5} \text { BOARD_INDEPEND }_{i, t-1}+\sum_{j} \beta_{j} \text { FIRM_CONTROL }_{j, i, t-1}+\sum_{h} \beta_{h} \text { COUNTRY_CONTROL }_{h, t}\right) \\
& \operatorname{Pr}\left(\text { MINIMALIST }_{i t}=1\right)=f\left(\beta_{1} \text { SIZE }_{i, t-1}+\beta_{2} R O E_{i, t-1}+\beta_{3} \text { BOARD_SIZE }_{i, t-1}+\beta_{4} \text { BOARD_MEET }_{i, t-1}+\right. \\
& \left.+\beta_{5} \text { BOARD_INDEPEND } D_{i, t-1}+\sum_{j} \beta_{j} \text { FIRM_CONTROL }_{j, i, t-1}+\sum_{h} \beta_{h} \text { COUNTRY_CONTROL }_{h, t}\right)
\end{aligned}
$$

In Equation (2), the dependent variable HOLISTIC is a dummy variable assuming value 1 for the companies included in the Holistic group, and 0 otherwise. Likewise, in Equation (3), (4), and (5) the dependent variable is replaced by INTEGRATED, CONSERVATIVE, and MINIMALIST dummy variables respectively. All the other variables in the regression models are the same presented under Eq. (1). See Table 2 for variables description. 


\section{Results}

\subsection{Companies' levels of integration}

This section examines the level of integration over the period 2002-2015 by: i) grouping companies based on their ITR_SCORE to categorize firms into four distinctive groups; and ii) using univariate analysis to assess firm characteristics across the ITR groups. From Table 3, across the sample period analysed, ITR_SCORE ranges from 8.42 (minimum) to 98.64 (maximum), with an average score of 69.56 and median value of 85.32. Higher median in comparison to the mean indicates a negatively skewed distribution, with more firm-year observations in the higher quartile distorting the mean. Both mean and median ITR_SCORE values stabilize from 2009-2010 onwards. Overall, a gradual increase in firm-year observations and median value show a positive trend over time highlighting an increasing attention towards integrating financial and non-financial information ${ }^{8}$.

[Table 3 near here]

Based on the distribution of ITR_SCORE for each year over 2002-2015, we categorize firms into four ITR groups: i) Holistic, when a company's ITR_SCORE in a year is higher than the third quartile value (>75p) for that year; ii) Integrated, when a company's ITR_SCORE in a year is lower than the third quartile value $(<75 \mathrm{p})$ and higher than the median value $(>50 \mathrm{p})$ for that year; iii) Conservative, when a company's ITR_SCORE in a year is lower than the median value $(<50 \mathrm{p})$ and higher than the first quartile value (>25p) for that year iv) Minimalist, when a company's ITR_SCORE in a year is lower than the first quartile value $(<25 \mathrm{p})$ for that year.

The percentage distribution of companies in the four ITR groups across countries and industries shows a higher percentage of companies from Spain, France, and Germany, and from Oil and Gas, Utilities, and Basic material industries, belonging to the Holistic group. Likewise, higher percentage of companies in the Minimalist category belongs to Luxembourg, Italy, and Ireland, and to Technology, Financials, and Healthcare industries ${ }^{9}$. This suggests some level of preference towards integrating financial and non-financial information across countries in the Euro STOXX 600 index and based on the industry the company is operating.

Table 4 presents the results of univariate analysis, where the four ITR groups are compared across a set of companies' characteristics (i.e. performance, size, risk, governance, and others). The median value of each variable for each group (i.e. Holistic, Integrated, Conservative, and Minimalist) is compared to all other groups collectively using a non-parametric k-sample test on the equality of

\footnotetext{
${ }^{8}$ Year 2015 reports a lower number of observations as at the time of data collection (August 2016) a lower number of ITR_SCORE values was estimated and/or reported in Datastream.

${ }^{9}$ The figures representing the distribution of companies in the four ITR groups across countries and industries are not reported in the manuscript but available on request.
} 
medians ${ }^{10}$. From Table 4, it is interesting to note that companies belonging to a specific group report median values significantly different from the others on a wide number of firm-specific variables. In particular, Holistic and Minimalist companies present distinctive characteristics for most of the variables analysed, suggesting the existence of different extent of integration related to companies' characteristics. Although limited in its ability to explain tangible differences across groups, the univariate analysis presents first-hand information for identifying distinctive features of ITR. Consequently, a detailed description of the four ITR groups is provided below.

\section{[Table 4 near here]}

Holistic ITR: Holistic companies have levels of ITR_SCORE in the fourth quartile; these are the companies in the top $25 \%$ of the distribution. Results from Table 4 show that Holistic companies are significantly different from the others in terms of performance, where absolute variables (i.e. RETAINED_EARNINGS, EBIT) and environmental performance (ENV_PERF) have higher median values, while relative variables (i.e. $R O A, R O E, R O S$, TOBIN_Q) report slightly lower median values. Holistic companies have higher size across all the measures used (i.e. EMPLOYEE, SALES, TOT_ASSETS, MARKETCAP), larger boards (BOARD_SIZE), more research and development investment $(R \& D)$, higher number of analysts following (ANALYSTS) and are older firms (FIRM_AGE). Also, Holistic companies present higher concentration in some industries, i.e. Oil and Gas, Utilities, and Basic Materials, and countries, i.e. Spain, France, and Germany.

Minimalist ITR: Minimalist companies have levels of ITR_SCORE lower than the first quartile value $(<25 \mathrm{p})$ and are in the bottom $25 \%$ of the distribution. Minimalist companies significantly differ from others as they report lower absolute performance values (i.e. RETAINED_EARNINGS, EBIT) and environmental performance ( $\left.E N V_{-} P E R F\right)$, while slightly higher values of performance ratios (i.e. ROA, ROE, ROS, TOBIN_Q). These companies are smaller, in terms of size (EMPLOYEE, SALES, TOT_ASSETS, MARKET_CAP), have smaller boards (BOARD_SIZE), lower research and development investments $(R \& D)$, fewer analysts following (ANALYSTS), and are younger firms (FIRM_AGE). Minimalist companies have higher concentration in Technology, Healthcare, and Financials industries, and in specific countries, i.e. Luxembourg, Italy, and Ireland.

Integrated and Conservative ITR: Integrated companies have levels of ITR_SCORE higher than the median value and lower than the third quartile value and are the companies in the top 50-75\% of the distribution. Conservative companies have levels of ITR_SCORE higher than the first quartile but lower than the median value, and are the companies in the bottom $25-50 \%$ of the distribution. Integrated and Conservative companies represent the two intermediate groups, thus tend to report characteristics similar to the closest group, i.e. Integrated with Holistic, Conservative with

\footnotetext{
${ }^{10}$ The non-parametric test for equality of median between unmatched data is estimated using the chi square test statistics computed using the continuity correction (Mann \& Whitney, 1947).
} 
Minimalist. It is worth noting that, moving from Holistic to Minimalist, variables like size, research and development, number of analysts, firm's age, and absolute performance measures progressively decrease, while other variables show mixed results.

Although the univariate analysis represents a good statistical tool to draw broad understanding of companies' level of integration and their idiosyncratic characteristics, it does not allow to draw inferences on the causal relationship. This requires further analysis to draw reliable conclusions which is presented in the Section 4.3.

\subsection{ITR and Switching Behaviour}

Figure 1 shows the switching behaviour of the sample firms by reporting the average percentage of companies in the same ITR group or switching from one to another over the period 2002-2015. It is interesting to note that a high percentage of Holistic (72\%) and Minimalist (75\%) firms maintain their level of integration from one year to another. Among the other groups, companies tend to switch between Holistic-Integrated (22\%) and Minimalist-Conservative (17\%), while it is rare for companies to switch from Holistic to Minimalist, and vice versa.

[Figure 1 near here]

These results point towards consistency in ITR levels; over time companies tend to maintain it or at times switch to the closest group. In doing so, integration seems to be a manifestation of the corporate culture and based on what a firm has done in the past (routine). Similarly, the level of integration is also related to what other firms do, especially in the same industry (imitation). These findings point towards the new institutional theory framework and, specifically, the concept of isomorphism, according to which organizations experience pressures that lead them to adopt rules and structures to enhance legitimacy (Deephouse, 1996; DiMaggio \& Powell, 1983). Organizations become isomorphic and tend to adopt similar rules and structures of companies in a similar position (De Villiers \& Alexander, 2014). Among the three types of isomorphic forces identified by DiMaggio and Powell (1983), i.e. mimetic, coercive, and normative, our findings on ITR and switching behaviour seem to confirm the mimetic aspect: large multinational companies benchmark against their peers and smaller companies benchmark against industry leaders (De Villiers \& Alexander, 2014) thus leading to imitation. A switching behaviour characterized by routine and imitation suggests that integration requires a 'one-off' investment; in other words, once a company achieves a level of integration of financial and non-financial information, it mostly tends to maintain the same over time. 


\subsection{Regression Results}

Table 5 reports the results of the panel data random effect regression (Panel A) and the ordered logistic panel data random effect regression (Panel B) to investigate what drives the ITR levels ${ }^{11}$. Findings from model 1 (Table 5, Panel A) show that companies' size (SIZE) and leverage (LEVERAGE) have a positive and significant impact on the level of integration, while company's performance $(R O E)$ reports a positive but non-significant impact. The ability to manage the environmental performance and reduce environmental risks $\left(E N V_{-} P E R F\right)$ seems to be a determining factor leading to higher companies' integration level as well as companies operating in environmental sensitive industries (IND_SENS) tend to exhibit higher integration levels. Among governance characteristics, bigger size of the board (BOARD_SIZE) is found to have a significant positive impact on ITR score, while no significant result is found for the other governance variables (BOARD_MEET, BOARD_INDEPEND, STRATEGIC_SHARE). Macroeconomic variables GDP and $M A R K E T \_I N D E X$ are positively related to ITR score; similarly, the level of investor protection of the country where the company operates (INV_PROT) seems to facilitate higher integration levels, while the country environmental performance index (EPI_INDEX), the World Bank country measures (VOICE_ACC_WB, REG_QUAL_WB, GOV_EFF_WB) and media freedom (FREEDOM) report nonsignificant results. In Table 5, Panel $\mathrm{B}$, the dependent variable is replaced by an ordinal variable assuming values $1,2,3$, and 4 , respectively for companies in the fourth, third, second, and first quartile of the ITR_SCORE distribution. Results from the ordered logistic panel data random effect regression reported in Panel B are in line with the findings reported in Panel A. It is interesting to note that, in the ordered regression specification, the variables BOARD_MEET, EPI_INDEX and some country variables report significant results. However, in order to provide an in-depth discussion of these findings, and their implications, it is crucial to first estimate the results from the regressions in Eq. (2), (3), (4), and (5).

[Table 5 near here]

Table 6 reports the results of the logit panel data random effect regressions that investigate the factors affecting the probability that a company has a Holistic (Table 6, columns 1-2), Integrated (Table 6, columns 3-4), Conservative (Table 6, columns 5-6) or a Minimalist (Table 6, columns 7-8) integration level.

[Table 6 near here]

Consistent with $\mathrm{H}_{1}$, firms with greater size (SIZE) are more likely to have either a Holistic or an Integrated level of integration, and this is in line with previous literature showing that size is a

\footnotetext{
${ }^{11}$ In Table 5, both for Panel A and Panel B, we present the findings of a core model (columns 1 and 2) and an extended model (columns 3 to 10). In the extended model, more country variables are added alternatively to avoid multicollinearity issues.
} 
significant predictor of companies' disclosure strategies (i.e. Cowen et al., 1987; Frías-Aceituno et al., 2013, 2014; Patten, 1991, 2002; Qiu et al., 2016). Larger companies tend to receive more attention from the general public, are under pressure to exhibit their social responsibility, and have a wider stakeholder base, compared to smaller companies which may have lower public pressure and fewer stakeholders (Cowen et al., 1987). In line with these results, firms with smaller size are found to be more likely to adopt either Conservative or Minimalist ITR level. The nature of the industry (IND_SENS) is also a decisive factor affecting ITR levels; firms in environmentally-sensitive sectors (i.e. chemicals, electricity, gas, waste water, alternative energy, forestry and paper) may feel higher pressure and thus exhibit higher probability to adopt a Holistic level of integration (Cormier et al., 2005; Cowen et al., 1987; Patten, 2002). These results are consistent with the predictions of the legitimacy theory, according to which corporations will do whatever they regard as necessary in order to preserve their image as a legitimate business and can even change the type of disclosure as a legitimising strategy (De Villiers \& van Staden, 2006; O’Donovan, 2002; Patten, 1991, 2002). The implementation of IR results in stronger internal communications, requires managers to engage in IT and develop new ways of measuring, managing and disclosing information (De Villiers et al., 2017b). Hence, firms with more social pressure are more likely to consider reporting in an integrated manner that jointly accounts for environmental, human, social, and natural principles. Contrary to previous literature (i.e. Grant, 1991; Qiu et al., 2016; Russo \& Fouts, 1997), performance variable (ROE) reports a non-significant coefficient, thus profitability $\left(\mathrm{H}_{2}\right)$ is not found to be a decisive factor that drives management to undertake higher levels of integration in day to day decision making (as in Cormier et al., 2005). Highly levered firms (LEVERAGE) are also found to be more likely to engage in high level of integration, i.e. a firm with more debt, and therefore higher riskiness, may feel obliged to explain how the funds are used. The ability of a company to avoid environmental risks and capitalize on environmental opportunities to generate long term value creation $\left(E N V_{-} P E R F\right)$ results into higher levels of integration. Environmental performance is increasingly an important issue for investors, potential investors and other stakeholders (De Villiers \& van Staden, 2011); our results show that the better a company is able to manage its impact on living and non-living natural systems, including the air, land and water, as well as complete ecosystems, the more probable would be to have higher levels of integration in daily decision-making processes. Among governance variables, firms with bigger board size (BOARD_SIZE) and more meetings (BOARD_MEET) are more likely to engage in higher integration, therefore enhancing accountability with stakeholders (Lai et al., 2018), while board composition (BOARD_INDEPEND) and CEO compensation (CEO_SHARE) do not turn out to be significant factors for Holistic level of integration. A joint analysis of the size and activity of the board suggests that the level of integration benefits from large boards, that may imply directors with more varied skills and experience, as well as a higher number of meetings; on the other hand, 
board independence does not seem to play a key role in supporting integration (Frìas-Aceituno et al., 2013; Prado-Lorenzo \& García-Sánchez, 2010). Thus, $\mathrm{H}_{3}$ and $\mathrm{H}_{4}$ are supported by these findings, while it is not the case for $\mathrm{H}_{5}$.

However, there are few notable differences in the results when comparing the predictors of the probability of belonging to the Holistic group with those of the Minimalist. Indeed, the coefficients of SIZE, LEVERAGE, and BOARD_SIZE become negative and significant, implying that firms with smaller size, lower level of debt to equity and smaller corporate boards are more likely to adopt a Minimalist approach. Looking at the companies that exhibit lower integration levels (i.e. Conservative and Minimalist), we can observe a negative relationship with the dependent variable for size (negative and significant) and performance (negative but not significant). This seems to suggest that size is a crucial factor in determining the level of integration in decision making processes; large firms are in a better position to do integrated thinking and reporting as they have the required resources and they can make all the efforts (i.e. "boots and all") to bring integration within the organization; on the other side, small firms simply don't do it because they do not seem to have the necessary resources, capacity, maybe incentives, to be more integrated. Similar results are found for board size and board meetings (negative and significant for Minimalist or Conservative) suggesting that the involvement of managers with sufficient experience and diversity, which are common with large boards, along with increased supervision and control are linked to higher integration levels. When CEO compensation is linked to shareholder returns (CEO_SHARE), companies seem to exhibit a lower probability of adopting a Minimalist ITR level. This may serve as a motivation to induce CEO towards higher level of integration thereby addressing any potential principle-agent problem. Despite previous literature shows that active boards are more effective in performing supervisory functions, leading to lower information asymmetry and greater interest in disclosing information to stakeholders (FríasAceituno et al., 2013), our findings show that only the size of the board and the number of board meetings represent significant factors affecting the level of integration. Integration emerges as a journey, characterised by challenges, success, strengths and weaknesses (Rinaldi et al., 2018); our analysis focuses on the phase of idea production and shows that, although the journey can lead to different forms of resistance, it has a transformative potential that may lead to a more integrated conception of value (McNally \& Maroun, 2018).

The macroeconomic environment also plays a key role in defining the level of integration; in particular, the higher the economic growth $(G D P)$ and market performance (MARKET_INDEX), the greater the probability of adopting a Holistic integration level in line with García-Sánchez et al. (2013), Jensen and Berg (2012), Vaz et al. (2016). Following the arguments presented by De Villiers and Marques (2016), firms in countries that show a greater commitment to environmental issues could be more likely to provide more information as a result of higher levels of stakeholder pressure; 
however, at the same time, in more environmentally committed countries, environmental issues may lead to negative financial consequences. Our findings point towards the first interpretation for the Minimalist companies; indeed, companies operating in countries with higher levels of environmental commitment (EPI_INDEX) tend to have Minimalist (or Conservative) levels of integration; on the other side, Holistic (or Integrated) companies seem less sensitive to stakeholder environmental pressure at country level. While previous literature shows IR companies are more likely to originate from countries with higher investor protection (Jensen \& Berg, 2012), our findings show no significant effect of the level of investor protection at country level (INV_PROT) on companies' level of integration in their internal processes. The democracy and freedom of the citizens in a country $\left(V O I C E \_A C C_{-} W B^{12}\right)$ seems to have a positive and significant effect on companies' internal decisionmaking processes, resulting into higher levels of integration.

\subsection{Robustness Checks}

To ensure the reliability of the results and avoid potential biases specifically related to industry classifications and the period of analysis, further robustness checks are undertaken. First, the regression models are re-estimated for non-financial firms (Subsample 1: Non-financial firms) to account for potential bias resulting from considering financial and non-financial companies jointly. Second, the analysis is repeated across different sub-periods, following the global financial crisis (Subsample 2: After 2007) and following the introduction of the IIRC framework (Subsample 3: After 2013). These robustness tests are reported for companies in the Holistic and Minimalist groups, as these groups displayed the most significant differences based on the previous analysis.

Results are provided in Table 7. The subsample analysis confirms that the results are robust across the different timelines, and that recent years exhibit consistency across drivers of firm ITR levels. Overall the robustness tests point towards reliability of estimates and are mostly consistent with prior evidence (Table 5 and 6).

[Table 7 near here]

\section{Discussion and Conclusion}

This article extends current knowledge in the field of integrated thinking and reporting by providing new empirical evidence on the nature of ITR and its determinants for a sample of European listed companies over 2002-2015. We complement previous studies in the field (i.e. Frías-Aceituno et al.,

\footnotetext{
${ }^{12}$ In unreported tables, the variable $V O I C E_{-} A C C_{-} W B$ is replaced by, in alternative, $R E G_{-} Q U A L_{-} W B, G O V_{-} E F F_{-} W B$, and FREEDOM to avoid multicollinearity issues. Variables are described in Table 2. Findings are consistent with the results displayed in Table 6.
} 
2013, 2014; Vaz et al., 2016) by measuring the level of integration (ITR level) as companies' management commitment towards integrating financial and extra-financial aspects (as in Maniora, 2015; Serafeim, 2015; Venter et al., 2016); this allows capturing different levels of integration, therefore distinctive ITR groups and their evolution over time. Through a comprehensive quantitative analysis, we extend the analysis of ITR determinants across the distinctive ITR levels, thus expanding the existing literature on the determinants of ITR practices and contributing to the debate on the future developments of ITR.

In our empirical analysis, we categorise firms into four ITR groups - Holistic, Integrated, Conservative, and Minimalist. Each of these has its own distinctive features and expresses a company's commitment towards the integration of financial and non-financial aspects, that is higher for Holistic companies (lowest for Minimalist). Results from univariate analysis show that companies with a Holistic or Integrated level tend to have bigger size, larger board, higher environmental performance, higher number of analysts following and are older firms. Differently, companies adopting a Minimalist or Conservative level are smaller in size, have smaller boards, lower environmental performance, lower R\&D investment and are relatively younger firms. Additionally, integration levels are also found to be concentrated by industry and country. The analysis of the switching behaviour shows that companies' ITR levels tend to be mostly consistent over time; in doing so, integration in thinking and reporting appears to be the result of routine and imitation. These findings point towards the concept of isomorphism, according to which organizations experience pressures that lead them to adopt rules and structures to enhance legitimacy (Deephouse, 1996; De Villiers \& Alexander, 2014; DiMaggio \& Powell, 1983). Our findings on ITR and switching behaviour seem to confirm the mimetic aspect of isomorphism (DiMaggio and Powell, 1983): large multinational companies benchmark against their peers and smaller companies benchmark against industry leaders (De Villiers \& Alexander, 2014) thus leading to imitation. This is interesting from both company and policy perspective, as it seems to suggest that once a more integrated approach in thinking and reporting is achieved, it would tend to be maintained over time. These initial results have then been validated by more robust methodology to infer cause and effect relationship.

The findings from the regression analysis show that firms' behaviour towards ITR can be explained in the context of legitimacy theory and stakeholder theory. Distinctive factors are found to significantly drive companies' choices of integration. Companies with greater size, leverage, board size and meetings, as well as companies operating in sensitive industries and with higher environmental performance, are more likely to exhibit a Holistic (or Integrated) level of integration, while Minimalist (or Conservative) is driven by the same characteristics but in the opposite direction. Therefore, the research hypotheses related to company size $\left(\mathrm{H}_{1}\right)$, board size $\left(\mathrm{H}_{3}\right)$ and board meetings $\left(\mathrm{H}_{4}\right)$ are confirmed by the research findings, while the remaining research hypotheses related to 
profitability $\left(\mathrm{H}_{2}\right)$ and board independence $\left(\mathrm{H}_{5}\right)$ do not find support in the empirical analysis. Moreover, operating in countries with better economic growth levels, market performance, and citizens freedom, but lower environmental commitment, significantly contribute to higher levels of integration. This suggests that a company's level of integration is the result of a legitimation process, especially for bigger companies (De Villiers \& van Staden, 2006; O’Donovan, 2002), i.e. bigger corporations are more in the spotlight of public opinion, receive public pressure and, therefore, will do whatever they regard as necessary in order to preserve their image of a legitimate business (De Villiers \& van Staden, 2006). It is interesting to note that the findings are in opposite directions when comparing Holistic and Minimalist companies. It seems to suggest that large firms are in a better position to do integrated thinking and reporting as they have the required resources and they can make all the efforts (i.e. "boots and all") to bring integration within the organization; on the other side, small firms simply don't do it because they don't seem to have the necessary resources, capacity, maybe incentives, to be more integrated. Similar results are found for board size and board meetings suggesting that experienced and diverse boards, which are common with large boards, along with increased supervision and control lead to higher integration levels. These findings are confirmed across several model specifications and found to be robust across various sub sample analyses.

These results have some interesting implications for the corporate (and financial) reporting debate. This study offers significant evidence of the existence of different levels of integration in response to the need for transparency and improved communication, concluding that there is no unique recipe for achieving integration. The identification of the drivers of ITR levels, from Holistic to Minimalist, has the potential to inspire companies' choices alongside policymakers' initiatives, by identifying which levers should be pulled to achieve the desired level of integration. Moreover, the results point to the importance of legitimacy theory and stakeholder theory to explain integration, thus contributing to the theoretical framework on IR and IT research. Most importantly, as part of the debate on the future developments of IR, the results from this study suggest the need for a tailored approach rather than a one size fits all. Indeed, companies can have different levels of ITR and this is found to be driven by a variety of factors at company, governance, and country level.

From a practical perspective, our findings suggest that companies experience their own integration journey and there is no unique recipe for integration, i.e. one size does not fit all. This needs to be acknowledged by managers, who would be interested in understanding the role of both internal and external factors in affecting integration; by regulators, as future regulations need to be tailored according to company characteristics as well as contextual factors; by policymakers, for any future initiatives in the field of IT and IR; by capital market participants, who can use these results to inform their decisions. We also acknowledge the limitations of our study, that focuses on European listed companies (only) and a defined (although wide) period of investigation; similar to other studies, 
our measure of ITR, provided by Thomson Reuters Asset4, can be a limiting factor. It has the important advantage of ensuring objectivity (reducing any subjectivity from variables measured directly by the researchers) and allowing a comprehensive analysis, although limiting the possibility to follow the entire data collection process; however, we are confident that the informative power of this measure overcomes any potential limitation, and allows conducting an analysis that otherwise could not be done. Future research can expand into investigating the phenomenon across different geographic areas and the context of non-voluntary adoption of IR, as well as testing alternative measures and looking at non-observable characteristics. Moreover, findings from this study also open further opportunities to explore the specialization effects of ITR practices, i.e. by size, sector, and governance structure. 


\section{References}

Adams, C. A. (2015). The international integrated reporting council: a call to action. Critical Perspectives on Accounting, 27, 23-28.

Adams, R. B., Ferreira, D. (2012). Regulatory pressure and bank directors' incentives to attend board meetings. International Review of Finance, 12(2), 227-248.

Adams, C. A., Potter, B., Singh, P. J., York, J. (2016). Exploring the implications of integrated reporting for social investment (disclosures). The British Accounting Review, 48(3), 283-296.

Adams, S., Simnett, R. (2011). Integrated Reporting: An opportunity for Australia's not-for-profit sector. Australian Accounting Review, 21(3), 292-301.

Al-Htaybat, K., von Alberti-Alhtaybat, L. (2018). Integrated thinking leading to integrated reporting: case study insights from a global player. Accounting, Auditing \& Accountability Journal, 31(5), 1435-1460.

Ansoff, I. (1965). Corporate Strategy. New York: McGraw-Hill.

Arcay, M. R. B., Vazquez, M. F. M. (2005). Corporate characteristics, governance rules and the extent of voluntary disclosure in Spain. Advances in Accounting, 21, 299-331.

Belkaoui, A., Karpik, P. G. (1989). Determinants of the corporate decision to disclose social information. Accounting, Auditing \& Accountability Journal, 2(1).

Bernardi, C., Stark, A. W. (2016). Environmental, social and governance disclosure, integrated reporting, and the accuracy of analyst forecasts. The British Accounting Review, 50, 16-31.

Branco, M.C., Eugénio, T., Ribeiro, J. (2008). Environmental disclosure in response to public perception of environmental threats: The case of co-incineration in Portugal. Journal of Communication Management, 12(2), 136-151.

Brown, J., Dillard, J. (2014). Integrated reporting: on the need for broadening out and opening up. Accounting, Auditing \& Accountability Journal, 27(7), 1120-1156.

Burke, J. J., Clark, C. E. (2016). The business case for integrated reporting: Insights from leading practitioners, regulators, and academics. Business Horizons, 59(3), 273-283.

Busco, C., Frigo, M. L., Quattrone, P., Riccaboni, A. (2013). Redefining Corporate Accountability through Integrated Reporting. Strategic Finance, 8, 33-41.

Busco, C., Granà, F., Quattrone, P. (2017). Integrated Thinking. CIMA Research Executive Summary, 13(3), 1-26.

Campbell, D. J. (2000). Legitimacy theory or managerial reality construction? Corporate social disclosure in Marks and Spencer Plc corporate reports. Accounting Forum, 24(1), 80-100.

Cheng, E. C., Courtenay, S. M. (2006). Board composition, regulatory regime and voluntary disclosure. The International Journal of Accounting, 41(3), 262-289.

Cheng, B., Ioannou, I., Serafeim, G. (2014). Corporate social responsibility and access to finance. Strategic Management Journal, 35(1), 1-23.

Cho, C. H., Patten, D. M. (2007). The role of environmental disclosures as tools of legitimacy: A research note. Accounting, Organizations and Society, 32(7-8), 639-647.

Churet, C., Eccles, R. G. (2014). Integrated reporting, quality of management, and financial performance. Journal of Applied Corporate Finance, 26(1), 56-64.

Cohn, J. B., Rajan, U. (2013). Optimal corporate governance in the presence of an activist investor. The Review of Financial Studies, 26(4), 985-1020.

Comyns, B. (2016). Determinants of GHG reporting: an analysis of global oil and gas companies. Journal of Business Ethics, 136(2), 349-369.

Cormier, D., Magnan, M. (2014). The impact of social responsibility disclosure and governance on financial analysts' information environment. Corporate Governance, 14(4), 467-484. 
Cormier, D., Magnan, M., Van Velthoven, B. (2005). Environmental disclosure quality in large German companies: economic incentives, public pressures or institutional conditions? European Accounting Review, 14(1), 3-39.

Cowen, S. S., Ferreri, L. B., Parker, L. D. (1987). The impact of corporate characteristics on social responsibility disclosure: A typology and frequency-based analysis. Accounting, Organizations and Society, 12(2), 111-122.

De Villiers, C., Rinaldi, L., Unerman, J. (2014). Integrated Reporting: Insights, gaps and an agenda for future research. Accounting, Auditing \& Accountability Journal, 27(7), 1042-1067.

De Villiers, C., Venter, E. R., Hsiao, P. C. K. (2017a). Integrated reporting: background, measurement issues, approaches and an agenda for future research. Accounting \& Finance, 57(4), 937-959.

De Villiers, C., Hsiao, P. C. K., Maroun, W. (2017b). Developing a conceptual model of influences around integrated reporting, new insights and directions for future research. Meditari Accountancy Research, 25(4), 450-460.

De Villiers, C., Naiker, V., Van Staden, C. J. (2011). The effect of board characteristics on firm environmental performance. Journal of Management, 37(6), 1636-1663.

De Villiers, C., Alexander, D. (2014). The institutionalisation of corporate social responsibility reporting. The British Accounting Review, 46(2), 198-212.

De Villiers, C., Marques, A. (2016). Corporate social responsibility, country-level predispositions, and the consequences of choosing a level of disclosure. Accounting and Business Research, 46(2), 167-195.

De Villiers, C., Van Staden, C. J. (2006). Can less environmental disclosure have a legitimising effect? Evidence from Africa. Accounting, Organizations and Society, 31(8), 763-781.

De Villiers, C., Van Staden, C. J. (2011). Where firms choose to disclose voluntary environmental information. Journal of Accounting and Public Policy, 30(6), 504-525.

Deegan, C., Rankin, M., Voght, P. (2000). Firms' disclosure reactions to major social incidents: Australian evidence. Accounting Forum, 24(1), 101-30.

Deephouse, D. L. (1996). Does isomorphism legitimate?. Academy of management journal, 39(4), 1024-1039.

Del Baldo, M. (2017). The implementation of integrating reporting in SMEs: Insights from a pioneering experience in Italy. Meditari Accountancy Research, 25(4), 505-532.

Depoers, F., Jeanjean, T., Jérôme, T. (2016). Voluntary disclosure of greenhouse gas emissions: Contrasting the carbon disclosure project and corporate reports. Journal of Business Ethics, 134(3), 445-461.

DiMaggio, P., Powell, W. W. (1983). The iron cage revisited: Collective rationality and institutional isomorphism in organizational fields. American sociological review, 48(2), 147-160.

Donaldson, T., Preston, L. E. (1995). The stakeholder theory of the corporation: Concepts, evidence, and implications. The Academy of Management Review, 20(1), 65-91.

Dowling, J., Pfeffer, J. (1975). Organizational legitimacy: Social values and organizational behavior. Pacific sociological review, 18(1), 122-136.

du Toit, E. (2017). The readability of integrated reports. Meditari Accountancy Research, 25(4), 629653.

Dumay, J., Bernardi, C., Guthrie, J., Demartini, P. (2016). Integrated reporting: a structured literature review. Accounting Forum 40(3), 166-185.

Dumay, J., Dai, T. (2017). Integrated thinking as a cultural control?. Meditari Accountancy Research, 25(4), 574-604.

Eccles, R. G., Krzus, M. P. (2010). One report: Integrated reporting for a sustainable strategy. John Wiley \& Sons. 
Eccles, R. G., \& Serafeim, G. (2014). Corporate and integrated reporting: A functional perspective, available on the internet at https://hbswk.hbs.edu/item/corporate-and-integrated-reporting-afunctional-perspective Accessed 11.05.18.

Fama, E. F., Jensen, M. C. (1983). Separation of ownership and control. The Journal of Law and Economics, 26(2), 301-325.

Fedération des Experts Comptables Européens (2015). The Future of Corporate Reporting - creating the dynamics for change, available on the internet at https://www.accountancyeurope.eu/wpcontent/uploads/FEECogitoPaper__ TheFutureofCorporateReporting.pdf Accessed 11.05.18.

Ferreira, D. (2010). Board diversity. Oxford: John Wiley \& Sons.

Flower, J. (2015). The international integrated reporting council: a story of failure. Critical Perspectives on Accounting, 27, 1-17.

Freeman, R. E. (1984). Strategic Management: A stakeholder approach. Boston: Pitman.

Freeman, R. E. (2010). Strategic management: A stakeholder approach. Cambridge University Press.

Frías-Aceituno, J. V., Rodríguez-Ariza, L., García-Sánchez, I. M. (2013). The role of the board in the dissemination of integrated corporate social reporting. Corporate Social Responsibility and Environmental Management, 20(4), 219-233.

Frías-Aceituno , J. V., Rodríguez-Ariza, L., García-Sánchez, I. M. (2014). Explanatory factors of integrated sustainability and financial reporting. Business Strategy and the Environment, 23(1), 56-72.

Gandía, J. L. (2008). Determinants of internet-based corporate governance disclosure by Spanish listed companies. Online Information Review, 32(6), 791-817.

García-Sánchez, I. M., Rodríguez-Ariza, L., Frías-Aceituno, J. V. (2013). The cultural system and integrated reporting. International Business Review, 22(5), 828-838.

García-Sánchez, I. M., Rodríguez Domínguez, L., Gallego Álvarez, I. (2011). Corporate governance and strategic information on the internet: a study of Spanish listed companies. Accounting, Auditing \& Accountability Journal, 24(4), 471-501.

Gibassier, D., Rodrigue, M., Arjaliès, D. L. (2018). "Integrated reporting is like God: no one has met Him, but everybody talks about Him" The power of myths in the adoption of management innovations. Accounting, Auditing \& Accountability Journal, 31(5), 1349-1380.

Grant, R. M. (1991). The resource-based theory of competitive advantage: implications for strategy formulation. California Management Review, 33(3), 114-135.

Gray, R., Kouhy, R., Lavers, S. (1995). Corporate social and environmental reporting: a review of the literature and a longitudinal study of UK disclosure. Accounting, Auditing \& Accountability Journal, 8(2), 47-77.

Guthrie, J., Manes-Rossi, F., Orelli, R. L. (2017). Integrated reporting and integrated thinking in Italian public sector organisations. Meditari Accountancy Research, 25(4), 553-573.

Guthrie, J., Parker, L. D. (1989). Corporate social reporting: a rebuttal of legitimacy theory. Accounting \& Business Research, 19(76), 343-352.

Hackston, D., Milne, M. (1996). Some determinants of social and environmental disclosures in New Zealand. Accounting Auditing \& Accountability Journal, 9(1), 77-108.

Haller, A., van Staden, C. (2014). The value added statement-an appropriate instrument for Integrated Reporting. Accounting, Auditing \& Accountability Journal, 27(7), 1190-1216.

Henderson, S., Peirson, G., Herbohn, K., Howieson, B. (2015). Issues in financial accounting. Pearson Higher Education AU.

Herman, E. S. (1981). Corporate control, corporate power. Cambridge: Cambridge University Press.

Hidalgo, R. L., García-Meca, E., Martínez, I. (2011). Corporate governance and intellectual capital disclosure. Journal of Business Ethics, 100(3), 483-495. 
Higgins, C., Stubbs, W., Love, T. (2014). Walking the talk (s): Organisational narratives of integrated reporting. Accounting, Auditing \& Accountability Journal, 27(7), 1090-1119.

International Integrated Reporting Council (2013). International <IR > framework, available on the internet at http://integratedreporting.org/resource/international-ir-framework/ Accessed 11.05.18.

Jensen, J. C., Berg, N. (2012). Determinants of traditional sustainability reporting versus integrated reporting. An institutionalist approach. Business Strategy and the Environment, 21(5), 299316.

Jensen, M. C., Meckling, W. H. (1976). Theory of the firm: Managerial behavior, agency costs and ownership structure. Journal of Financial Economics, 3(4), 305-360.

Kanagaretnam, K., Lobo, G. J., Whalen, D. J. (2007). Does good corporate governance reduce information asymmetry around quarterly earnings announcements? Journal of Accounting and Public Policy, 26(4), 497-522.

Knauer, A., Serafeim, G. (2014). Attracting long- term investors through integrated thinking and reporting: a clinical study of a biopharmaceutical company. Journal of Applied Corporate Finance, 26(2), 57-64.

Karamanou, I., Vafeas, N. (2005). The association between corporate boards, audit committees, and management earnings forecasts: An empirical analysis. Journal of Accounting Research, 43(3), 453-486.

King IV (2016). Report on Corporate Governance for South Africa 2016, The Institute of Directors in Southern Africa NPC, available on the internet at http://www.iodsa.co.za/page/KingIVReport Accessed 11.05.18.

Lai, A., Melloni, G., Stacchezzini, R. (2018). Integrated reporting and narrative accountability: The role of preparers. Accounting, Auditing \& Accountability Journal, 31(5), 1381-1405.

Lai, A., Melloni, G., \& Stacchezzini, R. (2017). What does materiality mean to integrated reporting preparers? An empirical exploration. Meditari Accountancy Research, 25(4), 533-552.

Leftwich, R. W., Watts, R. L., Zimmerman, J. L. (1981). Voluntary corporate disclosure: The case of interim reporting. Journal of Accounting Research, 50-77.

Linck, J. S., Netter, J. M., Yang, T. (2008). The determinants of board structure. Journal of Financial Economics, 87(2), 308-328.

Lipton, M., Lorsch, J. W. (1992). A modest proposal for improved corporate governance. The Business Lawyer, 59-77.

Luo, X., Wang, H., Raithel, S., Zheng, Q. (2015). Corporate social performance, analyst stock recommendations, and firm future returns. Strategic Management Journal, 36(1), 123-136.

Macias, H. A., Farfan-Lievano, A. (2017). Integrated reporting as a strategy for firm growth: multiple case study in Colombia. Meditari Accountancy Research, 25(4), 605-628.

Maniora, J. (2015). Is integrated reporting really the superior mechanism for the integration of ethics into the core business model? An empirical analysis. Journal of Business Ethics, 1-32.

Mann, H. B., Whitney, D. R., (1947). On a test of whether one of two random variables is stochastically larger than the other. Annals of Mathematical Statistics, 18(1), 50-60.

Maroun, W. (2017). Assuring the integrated report: Insights and recommendations from auditors and preparers. The British Accounting Review, 49(3), 329-346.

McNally, M. A., Maroun, W. (2018). It is not always bad news: Illustrating the potential of integrated reporting using a case study in the eco-tourism industry. Accounting, Auditing \& Accountability Journal, 31(5), 1319-1348.

McNally, M. A., Cerbone, D., Maroun, W. (2017). Exploring the challenges of preparing an integrated report. Meditari Accountancy Research, 25(4), 481-504. 
Miller, G. S., Skinner, D. J. (2015). The evolving disclosure landscape: How changes in technology, the media, and capital markets are affecting disclosure. Journal of Accounting Research, 53(2), 221-239.

Milne, M. J., Gray, R. (2013). W(h)ither ecology? The triple bottom line, the global reporting initiative, and corporate sustainability reporting. Journal of Business Ethics, 118(1), 13-29.

Neu, D., Warsame, H., Pedwell, K. (1998). Managing public impressions: environmental disclosures in annual reports. Accounting, Organizations and Society, 23(3), 265-282.

O'Donovan, G. (2002). Environmental disclosures in the annual report: Extending the applicability and predictive power of legitimacy theory. Accounting, Auditing \& Accountability Journal, 15(3), 344-371.

O'Donovan, G. M., Gibson, K. M. (2000). Environmental disclosures in Australia: a longitudinal study. In School of Accounting \& Finance Internal Seminar Series (p. EJ).

Patten, D. M. (1991). Exposure, legitimacy and social disclosure. Journal of Accounting and Public Policy, 10(4), 297-308.

Patten, D. M. (2002). The relation between environmental performance and environmental disclosure: a research note. Accounting, Organizations and Society, 27(8), 763-773.

Prado-Lorenzo, J. M., Garcia-Sanchez, I. M. (2010). The role of the board of directors in disseminating relevant information on greenhouse gases. Journal of Business Ethics, 97(3), 391-424.

PwC (2013). Integrated Reporting. Going beyond the financial results, available on the internet at https://www.pwc.com/my/en/assets/services/1308-point-of-view-integrated-reporting.pdf Accessed 11.05.18.

PwC (2015). Implementing Integrated Reporting. PwC's practical guide for a new business language, available on the internet at http://www.pwc.com/gx/en/audit-services/publications/assets/pwcir-practical-guide.pdf Accessed 11.05.18.

Qiu, Y., Shaukat, A., Tharyan, R. (2016). Environmental and social disclosures: Link with corporate financial performance. The British Accounting Review, 48(1), 102-116.

Reimsbach, D., Hahn, R. Gürtürk, A. (2017). Integrated Reporting and Assurance of Sustainability Information: An Experimental Study on Professional Investors' Information Processing, European Accounting Review, 1-23.

Reverte, C. (2009). Determinants of corporate social responsibility disclosure ratings by Spanish listed firms. Journal of Business Ethics, 88(2), 351-366.

Rinaldi, L., Unerman, J., De Villiers, C. (2018). Evaluating the integrated reporting journey: insights, gaps and agendas for future research. Accounting, Auditing \& Accountability Journal, 31(5), 1294-1318.

Roberts, R. W. (1992). Determinants of corporate social responsibility disclosure: An application of stakeholder theory. Accounting, Organizations and Society, 17(6), 595-612.

Russo, M. V., Fouts, P. A. (1997). A resource-based perspective on corporate environmental performance and profitability. Academy of Management Journal, 40(3), 534-559.

Samaha, K., Khlif, H., Hussainey, K. (2015). The impact of board and audit committee characteristics on voluntary disclosure: a meta-analysis. Journal of International Accounting, Auditing and Taxation, 24, 13-28.

Serafeim, G. (2015). Integrated reporting and investor clientele. Journal of Applied Corporate Finance, 27(2), 34-51.

Silvestri, A., Veltri, S., Venturelli, A., Petruzzelli, S. (2017). A research template to evaluate the degree of accountability of integrated reporting: a case study. Meditari Accountancy Research, 25(4), 675-704. 
Simnett, R., Vanstraelen, A., Chua, W. F. (2009). Assurance on sustainability reports: An international comparison. The accounting review, 84(3), 937-967.

Steyn, M. (2014). Organisational benefits and implementation challenges of mandatory integrated reporting. Sustainability Accounting, Management and Policy Journal, 5(4), 476-503.

Ullmann, A. A. (1985). Data in search of a theory: A critical examination of the relationships among social performance, social disclosure, and economic performance of US firms. The Academy of Management Review, 10(3), 540-557.

Vafeas, N. (1999). Board meeting frequency and firm performance. Journal of Financial Economics, 53(1), 113-142.

van Bommel, K. (2014). Towards a legitimate compromise? An exploration of integrated reporting in the Netherlands. Accounting, Auditing \& Accountability Journal, 27(7), 1157-1189.

Vaz, N., Fernandez-Feijoo, B., Ruiz, S. (2016). Integrated reporting: an international overview. Business Ethics: A European Review, 25(4), 577-591.

Venter, E. R., Stiglingh, M., Smit, A. R. (2016). Integrated Thinking and the Transparency of Tax Disclosures in the Corporate Reports of Firms. Journal of International Financial Management \& Accounting, 28(3), 394-427.

Vesty, G. M., Ren, C., Ji, S. (2018). Integrated reporting as a test of worth: A conversation with the chairman of an integrated reporting pilot organisation. Accounting, Auditing \& Accountability Journal, 31(5), 1406-1434.

Walden, W. D., Schwartz, B. N. (1997). Environmental disclosures and public policy pressure. Journal of Accounting and Public Policy, 16(2), 125-154.

Zahra, S. A., Stanton, W. W. (1988). The implications of board of directors composition for corporate strategy and performance. International Journal of Management, 5(2), 229-236. 


\section{Table 1}

Sample distribution

\begin{tabular}{lrr}
\hline Panel A. Country & $\mathrm{N}$ & $\%$ \\
\hline Austria & 8 & 1.37 \\
Belgium & 14 & 2.40 \\
Czech Republic & 2 & 0.34 \\
Denmark & 19 & 3.26 \\
Finland & 15 & 2.57 \\
France & 77 & 13.21 \\
Germany & 62 & 10.63 \\
Greece & 3 & 0.51 \\
Ireland & 12 & 2.06 \\
Italy & 29 & 4.97 \\
Luxembourg & 7 & 1.20 \\
Netherlands & 27 & 4.63 \\
Norway & 9 & 1.54 \\
Portugal & 4 & 0.69 \\
Spain & 30 & 5.15 \\
Sweden & 42 & 7.20 \\
Switzerland & 53 & 9.09 \\
United Kingdom & 170 & 29.16 \\
\hline Total & 583 & 100.00 \\
\hline
\end{tabular}

\begin{tabular}{lrr}
\hline Panel B. Industry & $\mathrm{N}$ & $\%$ \\
\hline Basic Materials & 43 & 7.38 \\
Consumer Goods & 71 & 12.18 \\
Consumer Services & 77 & 13.21 \\
Financials & 135 & 23.16 \\
Health Care & 40 & 6.86 \\
Industrials & 128 & 21.96 \\
Oil \& Gas & 19 & 3.26 \\
Technology & 22 & 3.77 \\
Telecommunications & 22 & 3.77 \\
Utilities & 26 & 4.46 \\
\hline Total & 583 & 100.00 \\
\hline
\end{tabular}

Notes: This table reports descriptive statistics on the sample distribution. The sample is composed of 583 companies based in 18 European countries (Panel A) and belonging to 10 single-digit ICB (Panel B). 


\section{Table 2}

Variables description and data source

\begin{tabular}{|c|c|c|c|}
\hline Category & Variable name & Description & Data source \\
\hline \multirow[t]{5}{*}{ Integration } & ITR_SCORE & $\begin{array}{l}\text { Integrated Thinking and Reporting Score (percentage between } 0 \text { and 100) - a company's } \\
\text { management commitment and effectiveness towards the creation of an overarching vision } \\
\text { and strategy integrating financial and extra-financial aspects (see Appendix). }\end{array}$ & $\begin{array}{l}\text { Thomson Reuters Asset } 4 \\
\text { (mnemonic CGVS) }\end{array}$ \\
\hline & HOLISTIC & Dummy variable, $=1$ when $I T R \_S C O R E$ is higher than the third quartile value. & Authors' estimation from Asset4 \\
\hline & INTEGRATED & $\begin{array}{l}\text { Dummy variable, }=1 \text { when } I T R \_S C O R E \text { is lower than the third quartile value and higher than } \\
\text { the median value. }\end{array}$ & Authors' estimation from Asset4 \\
\hline & CONSERVATIVE & $\begin{array}{l}\text { Dummy variable, }=1 \text { when } I T R \_S C O R E \text { is lower than the median value and higher than the } \\
\text { first quartile value. }\end{array}$ & Authors' estimation from Asset4 \\
\hline & MINIMALIST & Dummy variable, $=1$ when ITR_SCORE is lower than the first quartile value. & Authors' estimation from Asset4 \\
\hline \multirow[t]{7}{*}{ Performance } & $R O A$ & Return on assets - ratio of earnings before interest and taxes to total assets. & Datastream \\
\hline & $R O E$ & Return on equity - ratio of net income to common equity. & Datastream \\
\hline & $\operatorname{ROS}$ & Return on sales - the ratio of earnings before interest and taxes to net sales. & Datastream \\
\hline & $T O B I N \_Q$ & Tobin $\mathrm{Q}$ - the ratio of total market value of a firm to its total asset value. & Datastream \\
\hline & RETAINED_EARNINGS & $\begin{array}{l}\text { Retained earnings - after tax earnings not distributed as dividends to shareholders or allocated } \\
\text { to a reserve account. }\end{array}$ & Datastream \\
\hline & EBIT & Earnings before interest expense and income taxes. & Datastream \\
\hline & ENV_PERF & $\begin{array}{l}\text { Company's environmental performance - a company's impact on living and non-living } \\
\text { natural systems, including the air, land and water, as well as complete ecosystems. }\end{array}$ & Thomson Reuters Asset4 \\
\hline \multirow[t]{5}{*}{ Size } & EMPLOYEE & Total number of employees. & Datastream \\
\hline & SALES & Net sales - gross sales and other operating revenue less discounts, returns, and allowances. & Datastream \\
\hline & SIZE & Logarithm of SALES. & Datastream \\
\hline & TOT_ASSETS & $\begin{array}{l}\text { Total assets - sum of total current assets, long term receivables, investment in unconsolidated } \\
\text { subsidiaries, other investments, net property plant and equipment and other assets. }\end{array}$ & Datastream \\
\hline & MARKET_CAP & Market capitalization - Market Price Year End * Common Shares Outstanding. & Datastream \\
\hline Risk & ZSCORE & $\begin{array}{l}\mathrm{Z} \text { score }- \text { sum of firm return on asset and equity to asset ratio divided by the standard deviation } \\
\text { of last } 4 \text { years return on asset. }\end{array}$ & $\begin{array}{l}\text { Authors' estimation } \\
\text { Datastream }\end{array}$ \\
\hline & LEVERAGE & Total debt divided by total assets. & Datastream \\
\hline \multirow[t]{5}{*}{ Governance } & BOARD_SIZE & Size of the board of directors. & Datastream \\
\hline & BOARD_ATTEND & Average board meeting attendance. & Datastream \\
\hline & BOARD_MEET & Number of board meetings. & Datastream \\
\hline & BOARD_INDEPEND & Percentage of independent directors. & Datastream \\
\hline & CEO_SHARE & Dummy variable, $=1$ when CEO compensation is linked to shareholder return. & Datastream \\
\hline
\end{tabular}


Other variables $R \& D$

ANALYSTS

FIRM_AGE

IND_SENS

Macroeconomic GDP

MARKET_INDEX

EPI_INDEX

INV_PROT

VOICE_ACC_WB

$R E G \_Q U A L \_W B$

GOV_EFF_WB

FREEDOM
Total amount of research and development investments.

Total number of analysts making recommendations for the security.

Firm age - number of years since company founded.

Industry sensitivity - dummy variable, $=1$ for firms operating in environmentally sensitive industries, 0 otherwise. Sensitive industries are identified by the SIC codes described in De Villiers and Marques (2016).

Gross domestic product collected at country level.

STOXX Europe 600 market index return.

Environmental performance index - a measure of environmental responsibility by country. Values can range between 0 and 100 .

The strength of investor protection index is an average of 3 indices - the extent of disclosure index, the extent of director liability index, and the ease of shareholder suit index.

Voice and Accountability - reflects perceptions of the extent to which a country's citizens are able to participate in selecting their government, as well as freedom of expression, freedom of association, and a free media.

Regulatory quality - reflects perceptions of the ability of the government to formulate and implement sound policies and regulations that permit and promote private sector development.

Government Effectiveness - reflects perceptions of the quality of public services, the quality of the civil service and the degree of its independence from political pressures, the quality of policy formulation and implementation, and the credibility of the government's commitment to such policies.

Freedom of press - the Index ranks 180 countries according to the level of freedom available to journalists, based on an evaluation of pluralism, independence of the media, quality of legislative framework and safety of journalists in each country.
Datastream

Datastream

IBES

Datastream

Bloomberg

Bloomberg

Yale Center for Environmental

Law and Policy

World Bank

World Bank

World Bank

World Bank

Reporters Without Borders

Notes: This table describes the variables used in the analysis, including definition and source. Integration variables are collected and built from Thomson Reuters Asset4. Firm specific (performance, size, risk, and other) and governance variables are sourced and built from Datastream and Thomson Reuters. Macroeconomic variables are collected from Bloomberg, World Bank, Yale Center for Environmental Law and Policy, and Reporters Without Borders. All firm specific variables are winsorised at $1 \%$ level. 


\section{Table 3}

Integrated thinking and reporting score (ITR_SCORE)

\begin{tabular}{crrrrrrr}
\hline Year & $\mathrm{N}$ & Mean & Min & $25 \%$ & $50 \%$ & $75 \%$ & Max \\
\hline 2002 & 264 & 60.19 & 21.60 & 21.60 & 62.07 & 92.04 & 98.62 \\
2003 & 268 & 62.07 & 13.18 & 28.52 & 68.20 & 90.91 & 98.17 \\
2004 & 373 & 63.51 & 12.73 & 21.91 & 71.58 & 95.64 & 98.64 \\
2005 & 449 & 65.68 & 13.47 & 35.71 & 76.56 & 96.45 & 97.99 \\
2006 & 456 & 65.78 & 14.52 & 36.56 & 78.04 & 95.57 & 97.63 \\
2007 & 481 & 66.03 & 12.58 & 36.06 & 82.88 & 93.46 & 95.55 \\
2008 & 490 & 68.70 & 11.05 & 40.74 & 86.50 & 93.27 & 95.25 \\
2009 & 498 & 71.97 & 10.90 & 51.28 & 88.90 & 93.43 & 94.73 \\
2010 & 514 & 73.80 & 9.72 & 58.07 & 88.55 & 93.06 & 94.40 \\
2011 & 529 & 73.06 & 9.11 & 57.24 & 88.01 & 92.38 & 94.82 \\
2012 & 539 & 73.13 & 8.66 & 58.36 & 87.69 & 91.69 & 94.51 \\
2013 & 548 & 73.97 & 8.67 & 59.68 & 87.69 & 91.75 & 94.54 \\
2014 & 570 & 72.95 & 8.42 & 58.91 & 86.91 & 92.20 & 94.88 \\
2015 & 339 & 71.98 & 9.73 & 57.16 & 87.32 & 92.72 & 94.76 \\
\hline Overall (2002-2015) & 6318 & 69.56 & 8.42 & 46.57 & 85.32 & 92.77 & 98.64 \\
\hline
\end{tabular}

Notes: This table reports descriptive statistics of ITR_SCORE for each year over the period investigated and for the whole period (2002-2015). See Table 2 and the appendix for details on this variable. 


\section{Table 4}

Univariate analysis

\begin{tabular}{|c|c|c|c|c|}
\hline ITR Level & HOLISTIC & INTEGRATED & CONSERVATIVE & MINIMALIST \\
\hline \multicolumn{5}{|l|}{ Integration } \\
\hline ITR_SCORE & $93.91 * * *$ & $90.71 * * *$ & $70.54 * * *$ & $21.67 * * *$ \\
\hline \multicolumn{5}{|l|}{ Performance } \\
\hline$R O A$ & $6.7 * * *$ & $6.9 * * *$ & $7.93 * * *$ & $7.89 * * *$ \\
\hline$R O E$ & $13.07 *$ & $12.97 *$ & $14.25 * * *$ & 13.62 \\
\hline$R O S$ & 12.95 & $11.52 * * *$ & $12.08^{* * *}$ & $14.75 * * *$ \\
\hline$T O B I N \_Q$ & $1.24 * * *$ & $1.29 * * *$ & $1.4 * * *$ & $1.46 * * *$ \\
\hline RETAINED_EARNINGS & $3.76 \mathrm{M}^{* * *}$ & $2.45 \mathrm{M}^{* * *}$ & $0.97 \mathrm{M}^{* * *}$ & $0.69 \mathrm{M} * * *$ \\
\hline EBIT & $1.62 \mathrm{M}^{* * *}$ & $1.03 \mathrm{M}^{* * *}$ & $0.41 \mathrm{M}^{* * *}$ & $0.3 \mathrm{M}^{* * *}$ \\
\hline$E N V \_P E R F$ & $92.26 * * *$ & $89.82 * * *$ & $76.84 * * *$ & $32.71 * * *$ \\
\hline \multicolumn{5}{|l|}{ Size } \\
\hline EMPLOYEE & $48.9 \mathrm{~K}^{* * *}$ & $31.8 \mathrm{~K}^{* * *}$ & $12.8 \mathrm{~K}^{* * *}$ & $6.4 \mathrm{~K}^{* * *}$ \\
\hline SALES & $13.2 \mathrm{M}^{* * *}$ & $9.6 \mathrm{M}^{* * *}$ & $3.5 \mathrm{M}^{* * *}$ & $1.78 \mathrm{M}^{* * *}$ \\
\hline TOT_ASSETS & $23.4 \mathrm{M}^{* * *}$ & $13.6 \mathrm{M}^{* * *}$ & $4.6 \mathrm{M}^{* * *}$ & $3.4 \mathrm{M}^{* * *}$ \\
\hline MARKET_CAP & $13 \mathrm{M}^{* * *}$ & $8.5 \mathrm{M}^{* * *}$ & $3.9 \mathrm{M} * * *$ & $2.94 \mathrm{M} * * *$ \\
\hline \multicolumn{5}{|l|}{ Risk } \\
\hline ZSCORE & $4.32 * *$ & 4 & 4.01 & $3.77 * *$ \\
\hline LEVERAGE & 0.26 & $0.26 * *$ & 0.25 & $0.23 * * *$ \\
\hline \multicolumn{5}{|l|}{ Governance } \\
\hline BOARD_SIZE & $12 * * *$ & $12 * * *$ & $10 * * *$ & $9 * * *$ \\
\hline BOARD_ATTEND & $95 * * *$ & 95 & 95 & $96 * *$ \\
\hline BOARD_MEET & $8 * *$ & $9 * * *$ & $8^{*}$ & $8^{* * *}$ \\
\hline BOARD_INDEPEND & $54.55 * * *$ & $55.56^{* * *}$ & $50 *$ & $50 * * *$ \\
\hline STRATEGIC_SHARE & $16^{* * *}$ & 21 & 22 & $25 * * *$ \\
\hline \multicolumn{5}{|l|}{ Other variables } \\
\hline$R \& D$ & $185 \mathrm{~K}^{* * *}$ & $108 \mathrm{~K}^{* * *}$ & $62 \mathrm{~K}^{* * *}$ & $50 \mathrm{~K}^{* * *}$ \\
\hline ANALYSTS & $25^{* * *}$ & $22 * * *$ & $17 * * *$ & $13 * * *$ \\
\hline FIRM_AGE & $89 * * *$ & $83^{* *}$ & $69 * * *$ & $60 * * *$ \\
\hline
\end{tabular}

Notes: This table reports the results of the univariate analysis presented in Section 3.3 and discussed in Section 4.1. Variables are described in Table 2. *,**,*** denote significance at $10 \%, 5 \%$, and $1 \%$ levels respectively. $\mathrm{K}$ represents thousands, $\mathrm{M}$ represents Millions of Euros. 
Table 5

Panel data regression results: the determinants of ITR score

Panel A: dependent variable ITR_SCORE

\begin{tabular}{|c|c|c|c|c|c|c|c|c|c|c|}
\hline \multirow{3}{*}{ Variable } & \multicolumn{2}{|c|}{ Panel data $R E$} & \multicolumn{2}{|c|}{ Panel data $R E$} & \multicolumn{2}{|c|}{ Panel data RE } & \multicolumn{2}{|c|}{ Panel data $R E$} & \multicolumn{2}{|c|}{ Panel data $R E$} \\
\hline & Coeff. & Rob.SE & Coeff. & Rob.SE & Coeff. & Rob.SE & Coeff. & Rob.SE & Coeff. & Rob.SE \\
\hline & $(1)$ & $(2)$ & $(3)$ & $(4)$ & $(5)$ & (6) & (7) & (8) & (9) & (10) \\
\hline$S I Z E$ & $2.586^{* * *}$ & 0.462 & $2.701 * * *$ & 0.462 & $2.690 * * *$ & 0.460 & $2.714 * * *$ & 0.457 & $2.712 * * *$ & 0.459 \\
\hline$R O E$ & 0.002 & 0.012 & 0.001 & 0.013 & 0.001 & 0.013 & 0.001 & 0.013 & 0.001 & 0.013 \\
\hline BOARD_SIZE & $0.351 * *$ & 0.136 & $0.314 * *$ & 0.144 & $0.325^{* *}$ & 0.144 & $0.266^{*}$ & 0.0143 & $0.298 * *$ & 0.141 \\
\hline BOARD_MEET & 0.135 & 0.096 & 0.124 & 0.095 & 0.127 & 0.094 & 0.102 & 0.095 & 0.118 & 0.095 \\
\hline BOARD_INDEPEND & 0.005 & 0.018 & 0.019 & 0.017 & 0.019 & 0.017 & 0.018 & 0.017 & 0.018 & 0.017 \\
\hline LEVERAGE & $8.357 * * *$ & 3.208 & $7.807 * *$ & 3.022 & $7.768^{* *}$ & 2.998 & $7.288 * *$ & 3.032 & $7.690 * *$ & 3.011 \\
\hline STRATEGIC_SHARE & -0.014 & 0.023 & 0.005 & 0.021 & 0.005 & 0.021 & 0.005 & 0.021 & 0.004 & 0.022 \\
\hline CEO_SHARE & $2.305 * *$ & 1.049 & $2.084 * *$ & 1.031 & $2.066^{* * *}$ & 1.034 & $2.091 * *$ & 1.029 & $2.104 * *$ & 1.035 \\
\hline$E N V_{-} P E R F$ & $0.566^{* * *}$ & 0.026 & $0.596 * * *$ & 0.027 & $0.597 * * *$ & 0.027 & $0.594 * * *$ & 0.027 & $0.596 * * *$ & 0.026 \\
\hline IND_SENS & $5.068^{* * *}$ & 1.413 & $4.821 * * *$ & 1.368 & $4.816^{* * *}$ & 1.365 & $4.794 * * *$ & 1.370 & $4.808 * * *$ & 1.367 \\
\hline$G D P$ & $0.001 *$ & 0.001 & 0.001 & 0.001 & 0.001 & 0.001 & 0.001 & 0.001 & 0.001 & 0.001 \\
\hline MARKET_INDEX & $3.255^{* * *}$ & 0.950 & $2.996 * * *$ & 0.944 & $3.101 * * *$ & 0.943 & $2.894 * *$ & 0.930 & $2.985^{* * *}$ & 0.954 \\
\hline$E P I \_I N D E X$ & -0.042 & 0.050 & -0.042 & 0.048 & -0.045 & 0.047 & -0.029 & 0.049 & -0.052 & 0.075 \\
\hline INV_PROT & & & $1.035 * *$ & 0.495 & $0.948 * *$ & 0.462 & $1.012 * *$ & 0.487 & $1.022 * *$ & 0.489 \\
\hline$V O I C E \_A C C \_W B$ & & & 1.852 & 3.944 & & & & & & \\
\hline$R E G \_Q U A L_{-} W B$ & & & & & 1.469 & 1.871 & & & & \\
\hline$G O V_{-} E F F_{-} W B$ & & & & & & & -2.482 & 1.608 & & \\
\hline FREEDOM & & & & & & & & & 0.013 & 0.053 \\
\hline Intercept & $-17.115^{* *}$ & 7.743 & $-29.875 * * *$ & 11.396 & $-28.663 * * *$ & 9.008 & $-22.859 * *$ & 8.608 & $-26.316 * * *$ & 9.911 \\
\hline $\mathrm{N}$ & 4,130 & & 3,825 & & 3,825 & & 3,825 & & 3,825 & \\
\hline R-square overall & 0.5606 & & 0.5978 & & 0.5986 & & 0.5962 & & 0.5977 & \\
\hline
\end{tabular}


Panel B: dependent variable ordered ITR_SCORE

\begin{tabular}{|c|c|c|c|c|c|c|c|c|c|c|}
\hline \multirow{3}{*}{ Variable } & \multicolumn{2}{|c|}{ Panel data RE ordered } & \multicolumn{2}{|c|}{ Panel data RE ordered } & \multicolumn{2}{|c|}{ Panel data RE ordered } & \multicolumn{2}{|c|}{ Panel data RE ordered } & \multicolumn{2}{|c|}{ Panel data RE ordered } \\
\hline & Coeff. & Rob.SE & Coeff. & Rob.SE & Coeff. & Rob.SE & Coeff. & Rob.SE & Coeff. & Rob.SE \\
\hline & (1) & (2) & (3) & (4) & (5) & (6) & (7) & (8) & (9) & $(10)$ \\
\hline SIZE & $0.633 * * *$ & 0.09 & $0.778 * * *$ & 0.098 & $0.775 * * *$ & 0.098 & $0.792 * * *$ & 0.098 & $0.797 * * *$ & 0.099 \\
\hline BOARD_SIZE & $0.048 *$ & 0.026 & $0.060 *$ & 0.031 & $0.066^{* *}$ & 0.031 & $0.053 *$ & 0.031 & $0.051 *$ & 0.03 \\
\hline BOARD_MEET & $0.028^{*}$ & 0.016 & $0.039 * *$ & 0.017 & $0.040 * *$ & 0.017 & $0.038 * *$ & 0.017 & $0.036 * *$ & 0.017 \\
\hline BOARD_INDEPEND & -0.002 & 0.003 & 0.001 & 0.003 & -0.001 & 0.003 & -0.001 & 0.003 & 0.001 & 0.003 \\
\hline STRATEGIC_SHARE & 0.003 & 0.004 & 0.003 & 0.004 & 0.003 & 0.004 & 0.003 & 0.004 & 0.003 & 0.004 \\
\hline CEO_SHARE & 0.061 & 0.179 & 0.096 & 0.192 & 0.090 & 0.190 & 0.108 & 0.190 & 0.098 & 0.192 \\
\hline$E N V_{-} P E R F$ & $0.064 * * *$ & 0.005 & $0.075^{* * *}$ & 0.005 & $0.076^{* * *}$ & 0.005 & $0.075 * * *$ & 0.005 & $0.075 * * *$ & 0.005 \\
\hline IND_SENS & $1.054 * * *$ & 0.281 & $1.071 * * *$ & 0.297 & $1.062 * * *$ & 0.297 & $1.060 * * *$ & 0.299 & $1.057 * * *$ & 0.299 \\
\hline$G D P$ & $0.001 * *$ & 0.001 & $0.001 * * *$ & 0.001 & $0.001 * *$ & 0.001 & $0.001 * *$ & 0.001 & $0.001 * *$ & 0.001 \\
\hline MARKET_INDEX & $0.545^{* * *}$ & 0.163 & $0.483 * * *$ & 0.184 & $0.555 * * *$ & 0.183 & $0.517 * * *$ & 0.182 & $0.524 * * *$ & 0.185 \\
\hline$G O V \_E F F_{-} W B$ & & & & & & & 0.293 & 0.301 & & \\
\hline FREEDOM & & & & & & & & & -0.008 & 0.01 \\
\hline $\mathrm{N}$ & 4,130 & & 3,825 & & 3,825 & & 3,825 & & 3,825 & \\
\hline Log pseudolikelihood & -3647.167 & & -3213.929 & & -3211.471 & & -3216.287 & & -3216.423 & \\
\hline
\end{tabular}

Notes: This table reports the results of the panel data regressions on the determinants of ITR score. Panel A reports regression coefficients and robust standard errors for the panel data random effect regression, with ITR_SCORE as dependent variable (Eq.1). Panel B reports regression coefficients and robust standard errors for the ordered logistic panel data random effect regression, where the dependent variable is replaced by a categorical variable representing the four different ITR levels. In both Panel A and Panel B, we present the findings of a core model (columns 1 and 2) and an extended model (columns 3 to 10). In the extended model, more country variables are added alternatively to avoid multicollinearity issues. Variables are described in Table $2 . *, * *, * *$ denote significance at $10 \%, 5 \%$, and $1 \%$ levels respectively. 
Table 6

Panel data regression results: the determinants of ITR levels

\begin{tabular}{|c|c|c|c|c|c|c|c|c|}
\hline \multirow{3}{*}{ Variable } & \multicolumn{2}{|c|}{ HOLISTIC } & \multicolumn{2}{|c|}{ INTEGRATED } & \multicolumn{2}{|c|}{ CONSERVATIVE } & \multicolumn{2}{|c|}{ MINIMALIST } \\
\hline & Coeff. & Marg.eff. & Coeff. & Marg.eff. & Coeff. & Marg.eff. & Coeff. & Marg.eff. \\
\hline & (1) & (2) & (3) & (4) & (5) & (6) & (7) & (8) \\
\hline SIZE & $0.699 * * *$ & $0.076 * * *$ & $0.255^{* * *}$ & $0.037 * * *$ & $-0.630 * * *$ & $-0.076 * * *$ & $-0.740 * * *$ & $-0.043 * * *$ \\
\hline \multirow[t]{2}{*}{$R O E$} & -0.001 & -0.001 & 0.001 & 0.001 & -0.002 & -0.001 & -0.001 & -0.001 \\
\hline & $(0.003)$ & $(0.001)$ & $(0.002)$ & $(0.001)$ & $(0.002)$ & $(0.001)$ & $(0.004)$ & $(0.001)$ \\
\hline BOARD_SIZE & $0.083 * * *$ & $0.009 * * *$ & -0.034 & -0.005 & -0.005 & -0.001 & $-0.076 * *$ & $-0.004 * *$ \\
\hline \multirow[t]{2}{*}{ BOARD_MEET } & $0.040^{*}$ & $0.004 *$ & 0.012 & 0.002 & $-0.031 *$ & $-0.004 *$ & -0.032 & -0.002 \\
\hline & $(0.022)$ & $(0.002)$ & $(0.017)$ & $(0.002)$ & $(0.018)$ & $(0.002)$ & $(0.025)$ & $(0.001)$ \\
\hline \multirow{2}{*}{ BOARD_INDEPEND } & 0.002 & 0.001 & 0.001 & 0.001 & 0.003 & 0.001 & -0.003 & -0.001 \\
\hline & $(0.003)$ & $(0.001)$ & $(0.003)$ & $(0.001)$ & $(0.003)$ & $(0.001)$ & $(0.004)$ & $(0.001)$ \\
\hline \multirow[t]{2}{*}{ LEVERAGE } & 0.934 & 0.101 & $0.968 * *$ & $0.140 * *$ & $-1.209 * *$ & $-0.147 * *$ & $-1.803 * *$ & $-0.104 * *$ \\
\hline & $(0.693)$ & $(0.075)$ & $(0.475)$ & $(0.069)$ & $(0.545)$ & $(0.067)$ & $(0.778)$ & $(0.045)$ \\
\hline \multirow[t]{2}{*}{$E N V \_P E R F$} & $0.078 * * *$ & $0.009 * * *$ & $0.039 * * *$ & $0.006 * * *$ & 0.005 & 0.001 & $-0.078 * * *$ & $-0.004 * * *$ \\
\hline & $(0.007)$ & $(0.001)$ & $(0.004)$ & $(0.001)$ & $(0.003)$ & $(0.001)$ & $(0.005)$ & $(0.001)$ \\
\hline \multirow[t]{2}{*}{$I N D \_S E N S$} & $0.657^{* *}$ & $0.071 * *$ & 0.259 & 0.038 & $-0.485^{*}$ & $-0.059^{*}$ & $-1.033 * *$ & $-0.060 * *$ \\
\hline & $(0.322)$ & $(0.034)$ & $(0.203)$ & $(0.029)$ & $(0.283)$ & $(0.035)$ & $(0.415)$ & $(0.024)$ \\
\hline \multirow[t]{2}{*}{$G D P$} & $0.001 * *$ & $0.001 * * *$ & -0.001 & -0.001 & -0.001 & -0.001 & -0.001 & -0.001 \\
\hline & $(0.001)$ & $(0.001)$ & $(0.001)$ & $(0.001)$ & $(0.001)$ & $(0.001)$ & $(0.001)$ & $(0.001)$ \\
\hline \multirow[t]{2}{*}{ MARKET_INDEX } & $0.646 * *$ & $0.070^{* *}$ & 0.008 & 0.001 & $-0.513 * *$ & $-0.062 * *$ & -0.077 & -0.004 \\
\hline & $(0.272)$ & $(0.029)$ & $(0.216)$ & $(0.031)$ & $(0.231)$ & $(0.028)$ & $(0.343)$ & $(0.020)$ \\
\hline EPI_INDEX & $-0.033 * * *$ & $-0.004 * * *$ & -0.007 & -0.001 & $0.027 * *$ & $0.003 * *$ & $0.036^{* *}$ & $0.002 * *$ \\
\hline
\end{tabular}




\begin{tabular}{|c|c|c|c|c|c|c|c|c|}
\hline & $(0.012)$ & $(0.001)$ & $(0.009)$ & $(0.001)$ & $(0.011)$ & $(0.001)$ & $(0.016)$ & $(0.001)$ \\
\hline$I N V_{-} P R O T$ & 0.068 & 0.007 & 0.003 & 0.001 & 0.103 & 0.012 & $-0.183^{*}$ & $-0.011^{*}$ \\
\hline$V O I C E \_A C C \_W B{ }^{a}$ & $2.071 * * *$ & $0.225 * * *$ & -0.641 & -0.093 & -0.789 & -0.096 & -0.023 & -0.001 \\
\hline \multirow[t]{2}{*}{ Intercept } & $-22.624 * * *$ & & $-7.409 * * *$ & & $6.918 * * *$ & & $15.024 * * *$ & \\
\hline & $(2.234)$ & & $(1.458)$ & & (1.730) & & $(2.626)$ & \\
\hline $\mathrm{N}$ & 3,825 & 3,825 & 3,825 & 3,825 & 3,825 & 3,825 & 3,825 & 3,825 \\
\hline
\end{tabular}

Notes: This table reports the results of the logit panel data random effect regression models Eq. (2), (3), (4), and (5) that investigate the determinants of ITR levels. Columns 1-2 reports regression coefficients, marginal effects, and standard errors in parenthesis for Eq. (2). Columns 3-4 report regression coefficients, marginal effects, and standard errors in parenthesis for Eq. (3). Columns 5-6 reports regression coefficients, marginal effects, and standard errors in parenthesis for Eq. (4). Columns 7-8 report regression coefficients, marginal effects, and standard errors in parenthesis for Eq. (5). Variables are described in Table 2. *, **, *** denote significance at $10 \%, 5 \%$, and $1 \%$ levels respectively.

${ }^{a}$ In unreported tables, the variable VOICE_ACC_WB is replaced by, in alternative: $R E G_{-} Q U A L_{-} W B, G O V_{-} E F F_{-} W B, F R E E D O M$. Findings are consistent with the results displayed in Table 6 . 


\section{Table 7}

Panel data regression results: subsample analysis for Holistic and Minimalist companies

\begin{tabular}{|c|c|c|c|c|c|c|c|c|c|c|c|c|}
\hline \multirow{4}{*}{ Variable } & \multicolumn{6}{|c|}{ Dependent variable: HOLISTIC } & \multicolumn{6}{|c|}{ Dependent variable: MINIMALIST } \\
\hline & \multicolumn{2}{|c|}{$\begin{array}{c}\text { Subsample 1: } \\
\text { non-financial firms }\end{array}$} & \multicolumn{2}{|c|}{$\begin{array}{c}\text { Subsample 2: } \\
\text { after } 2007\end{array}$} & \multicolumn{2}{|c|}{$\begin{array}{c}\text { Subsample 3: } \\
\text { after } 2013\end{array}$} & \multicolumn{2}{|c|}{$\begin{array}{c}\text { Subsample 1: } \\
\text { non-financial firms }\end{array}$} & \multicolumn{2}{|c|}{$\begin{array}{c}\text { Subsample 2: } \\
\text { after } 2007\end{array}$} & \multicolumn{2}{|c|}{$\begin{array}{c}\text { Subsample 3: } \\
\text { after } 2013\end{array}$} \\
\hline & Coeff. & Marg.eff. & Coeff. & Marg.eff. & Coeff. & Marg.eff. & Coeff. & Marg.eff. & Coeff. & Marg.eff. & Coeff. & Marg.eff. \\
\hline & (1) & (2) & (3) & (4) & (5) & (6) & (7) & (8) & (9) & (10) & (11) & (12) \\
\hline \multirow[t]{2}{*}{ SIZE } & $0.675^{* * *}$ & $0.077 * * *$ & $0.822 * * *$ & $0.073 * * *$ & $0.967 *$ & 0.034 & $-0.754 * * *$ & $-0.042 * * *$ & $-0.787 * * *$ & $-0.034 * * *$ & $-1.546 * * *$ & $-0.037 * * *$ \\
\hline & $(0.104)$ & $(0.011)$ & $(0.140)$ & $(0.012)$ & $(0.560)$ & $(0.022)$ & $(0.135)$ & $(0.008)$ & $(0.167)$ & $(0.008)$ & $(0.587)$ & $(0.013)$ \\
\hline \multirow[t]{2}{*}{$R O E$} & -0.002 & -0.001 & -0.003 & -0.001 & -0.009 & -0.001 & 0.003 & 0.001 & -0.001 & -0.001 & 0.012 & 0.001 \\
\hline & $(0.003)$ & $(0.001)$ & $(0.004)$ & $(0.001)$ & $(0.018)$ & $(0.001)$ & $(0.004)$ & $(0.001)$ & $(0.005)$ & $(0.001)$ & $(0.019)$ & $(0.001)$ \\
\hline \multirow[t]{2}{*}{ BOARD_SIZE } & $0.083^{* * *}$ & $0.009 * * *$ & $0.123 * * *$ & $0.011 * * *$ & $0.497 * *$ & $0.017 * *$ & $-0.096 * *$ & $-0.005 * *$ & $-0.083^{*}$ & $-0.004 *$ & -0.138 & -0.003 \\
\hline & $(0.028)$ & $(0.003)$ & $(0.038)$ & $(0.003)$ & $(0.201)$ & $(0.009)$ & $(0.04)$ & $(0.002)$ & $(0.047)$ & $(0.002)$ & $(0.127)$ & $(0.003)$ \\
\hline \multirow[t]{2}{*}{ BOARD_MEET } & $0.039 *$ & $0.004 *$ & $0.055^{*}$ & $0.005^{*}$ & $0.312 * *$ & $0.011 * *$ & -0.034 & -0.002 & -0.012 & -0.001 & -0.050 & -0.001 \\
\hline & $(0.022)$ & $(0.002)$ & $(0.029)$ & $(0.003)$ & $(0.133)$ & $(0.005)$ & $(0.026)$ & $(0.001)$ & $(0.033)$ & $(0.001)$ & $(0.093)$ & $(0.002)$ \\
\hline \multirow[t]{2}{*}{ BOARD_INDEPEND } & 0.002 & 0.001 & 0.006 & 0.001 & $0.057 * * *$ & $0.002 * *$ & -0.001 & -0.001 & -0.004 & -0.001 & -0.003 & -0.001 \\
\hline & $(0.003)$ & $(0.001)$ & $(0.005)$ & $(0.001)$ & $(0.022)$ & $(0.001)$ & $(0.004)$ & $(0.001)$ & $(0.005)$ & $(0.001)$ & $(0.013)$ & $(0.001)$ \\
\hline \multirow[t]{2}{*}{ LEVERAGE } & 0.881 & 0.100 & $1.729^{*}$ & $0.154 *$ & 4.881 & 0.171 & $-2.378 * * *$ & $-0.134 * * *$ & $-2.250 * *$ & $-0.098^{* *}$ & -4.202 & -0.102 \\
\hline & $(0.701)$ & $(0.080)$ & $(0.953)$ & $(0.086)$ & (3.682) & $(0.134)$ & $(0.836)$ & $(0.047)$ & $(0.967)$ & $(0.043)$ & $(2.631)$ & $(0.063)$ \\
\hline \multirow[t]{2}{*}{ STRATEGIC_SHARE } & -0.006 & -0.001 & -0.007 & -0.001 & 0.022 & 0.001 & -0.006 & -0.001 & 0.009 & 0.001 & 0.023 & 0.001 \\
\hline & $(0.004)$ & $(0.001)$ & $(0.007)$ & $(0.001)$ & $(0.029)$ & $(0.001)$ & $(0.005)$ & $(0.001)$ & $(0.007)$ & $(0.001)$ & $(0.020)$ & $(0.001)$ \\
\hline \multirow[t]{2}{*}{ CEO_SHARE } & -0.081 & -0.009 & 0.240 & 0.021 & -0.032 & -0.001 & $-0.557 * *$ & $-0.031 * *$ & $-0.696 * *$ & $-0.030 * *$ & $-1.595^{*}$ & $-0.039 *$ \\
\hline & $(0.196)$ & $(0.022)$ & $(0.284)$ & $(0.025)$ & $(0.87)$ & $(0.031)$ & $(0.262)$ & $(0.015)$ & $(0.329)$ & $(0.014)$ & $(0.856)$ & $(0.021)$ \\
\hline \multirow[t]{2}{*}{$E N V_{-} P E R F$} & $0.076 * * *$ & $0.009 * * *$ & $0.091 * * *$ & $0.008^{* * *}$ & $0.247 * * *$ & $0.009 * * *$ & $-0.075 * * *$ & $-0.004 * * *$ & $-0.100 * * *$ & $-0.004 * * *$ & $-0.197 * * *$ & $-0.005 * * *$ \\
\hline & $(0.007)$ & $(0.001)$ & $(0.011)$ & $(0.001)$ & $(0.058)$ & $(0.003)$ & $(0.005)$ & $(0.001)$ & $(0.007)$ & $(0.001)$ & $(0.026)$ & $(0.001)$ \\
\hline \multirow[t]{2}{*}{ IND_SENS } & $0.711 * *$ & $0.081 * *$ & $0.758^{*}$ & $0.068^{*}$ & $2.816^{*}$ & 0.099 & $-1.141 * * *$ & $-0.064 * * *$ & $-1.206^{* *}$ & $-0.053^{* *}$ & $-2.330 *$ & $-0.056^{*}$ \\
\hline & $(0.318)$ & $(0.035)$ & $(0.431)$ & $(0.038)$ & $(1.485)$ & $(0.061)$ & $(0.429)$ & $(0.024)$ & $(0.524)$ & $(0.023)$ & (1.267) & $(0.029)$ \\
\hline \multirow[t]{2}{*}{$G D P$} & $0.001 * *$ & $0.001 * *$ & $0.001 * * *$ & $0.001 * * *$ & $0.002 * *$ & $0.001 * *$ & 0.001 & 0.001 & -0.001 & -0.001 & -0.001 & -0.001 \\
\hline & $(0.001)$ & $(0.001)$ & $(0.001)$ & -0.001 & $(0.001)$ & $(0.001)$ & $(0.001)$ & $(0.001)$ & $(0.001)$ & $(0.001)$ & $(0.001)$ & $(0.001)$ \\
\hline MARKET_INDEX & $0.635^{* *}$ & $0.072 * *$ & $0.679 * *$ & $0.061 * *$ & -3.541 & -0.124 & -0.063 & -0.004 & 0.171 & 0.008 & 3.331 & 0.081 \\
\hline
\end{tabular}




\begin{tabular}{|c|c|c|c|c|c|c|c|c|c|c|c|c|}
\hline & $(0.272)$ & $(0.031)$ & $(0.325)$ & $(0.029)$ & (5.078) & $(0.18)$ & $(0.35)$ & $(0.020)$ & $(0.394)$ & $(0.017)$ & (4.269) & $(0.103)$ \\
\hline \multirow[t]{2}{*}{ EPI_INDEX } & $-0.034 * * *$ & $-0.004 * * *$ & $-0.026^{*}$ & $-0.002 *$ & 0.041 & 0.001 & $0.037 * *$ & $0.002 * *$ & 0.021 & 0.001 & 0.007 & 0.001 \\
\hline & $(0.012)$ & $(0.001)$ & $(0.014)$ & $(0.001)$ & $(0.094)$ & $(0.003)$ & $(0.017)$ & $(0.001)$ & $(0.019)$ & $(0.001)$ & $(0.079)$ & $(0.002)$ \\
\hline \multirow[t]{2}{*}{$I N V_{-} P R O T$} & 0.052 & 0.006 & 0.001 & 0.001 & 0.404 & 0.014 & $-0.210^{* *}$ & $-0.012 * *$ & $-0.241^{*}$ & $-0.011 *$ & $-0.669 * *$ & $-0.016^{* *}$ \\
\hline & $(0.091)$ & $(0.010)$ & $(0.124)$ & $(0.011)$ & $(0.416)$ & $(0.016)$ & $(0.103)$ & $(0.006)$ & $(0.123)$ & $(0.005)$ & $(0.313)$ & $(0.008)$ \\
\hline \multirow[t]{2}{*}{$V O I C E \_A C C \_W B$} & $1.988 * * *$ & $0.226 * * *$ & $2.295^{* *}$ & $0.205^{* *}$ & $11.025 * *$ & $0.387 * *$ & -0.282 & -0.016 & 0.275 & 0.012 & -1.765 & -0.043 \\
\hline & $(0.751)$ & $(0.085)$ & (1.000) & $(0.090)$ & $(4.379)$ & $(0.183)$ & (0.998) & $(0.056)$ & (1.179) & $(0.052)$ & $(2.950)$ & $(0.070)$ \\
\hline \multirow[t]{2}{*}{ Intercept } & $-21.609 * * *$ & & $-28.039 * * *$ & & $-80.098 * * *$ & $-80.098 * * *$ & $15.724 * * *$ & & $17.941 * * *$ & & $43.172 * * *$ & \\
\hline & $(2.214)$ & & (3.029) & & (20.624) & & $(2.729)$ & & (3.253) & & (13.227) & \\
\hline $\mathrm{N}$ & 3,637 & 3,637 & 3,164 & 3,164 & 746 & 746 & 3,637 & 3,637 & 3,164 & 3,164 & 746 & 746 \\
\hline Log pseudolikelihood & -1362.693 & & -1035.938 & & -309.166 & & -834.223 & & -681.733 & & -175.070 & \\
\hline
\end{tabular}

Notes: This table reports the results from the robustness checks on the Holistic and Minimalist ITR levels. Eq. (2) is estimated for the non-financial firms in the Holistic group (Columns 1-2), after 2007 (Columns 3-4) and after 2013 (Columns 5-6). Similarly, Eq. (5) is estimated for the non-financial firms in the Minimalist group (Columns 7-8), after 2007 (Columns 9-10) and after 2013 (Columns 11-12). For each regression, it reports coefficients, marginal effects, and standard errors in parenthesis. Variables are described in Table 2.*,**,*** denote significance at $10 \%, 5 \%$, and $1 \%$ levels respectively. 


\section{Figure 1}

ITR switching behaviour among groups

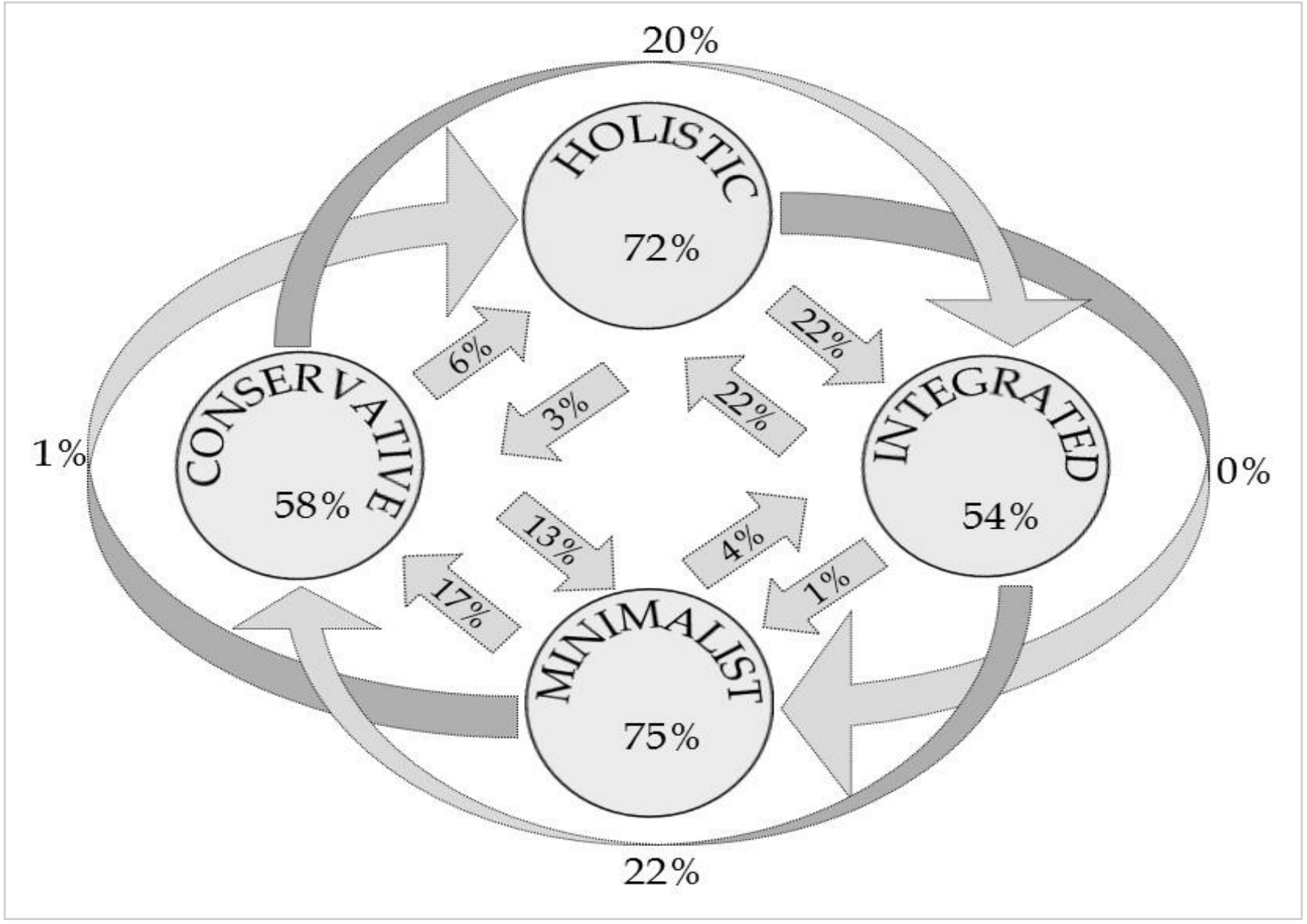

Notes: This Figure shows the distribution and the average percentage of firms that either maintain the ITR level (Holistic, Integrated, Conservative, and Minimalist) or switch from one year to another over the period 2002-2015. 


\section{Appendix}

Integrated Thinking and Reporting Score (ITR_SCORE) from Thomson Reuters Asset4

\begin{tabular}{|c|c|}
\hline Label & Description \\
\hline $\begin{array}{l}\text { Integration/Vision and Strategy } \\
\left(I T R \_S C O R E\right)\end{array}$ & $\begin{array}{l}\text { The integration/vision and strategy category measures a company's management } \\
\text { commitment and effectiveness towards the creation of an overarching vision and } \\
\text { strategy integrating financial and extra-financial aspects. It reflects a company's } \\
\text { capacity to convincingly show and communicate that it integrates the economic } \\
\text { (financial), social and environmental dimensions into its day-to-day decision- } \\
\text { making processes. (Asset } 4 \text { mnemonic CGVS) }\end{array}$ \\
\hline $\begin{array}{l}\text { Score - Vision and } \\
\text { Strategy/Policy }\end{array}$ & $\begin{array}{l}\text { Does the company have a policy for maintaining an overarching vision and } \\
\text { strategy that integrates financial and extra-financial aspects of its business? } \\
\text { (Asset } 4 \text { mnemonic CGVSD01S) }\end{array}$ \\
\hline $\begin{array}{l}\text { Score - Vision and } \\
\text { Strategy/Implementation }\end{array}$ & $\begin{array}{l}\text { Does the company describe the implementation of its integrated strategy through } \\
\text { a public commitment from a senior management or board member? AND Does } \\
\text { the company describe the implementation of its integrated strategy through the } \\
\text { establishment of a CSR committee or team? (Asset } 4 \text { mnemonic CGVSD02S) }\end{array}$ \\
\hline $\begin{array}{l}\text { Score - Vision and } \\
\text { Strategy/Monitoring }\end{array}$ & $\begin{array}{l}\text { Does the company monitor its integrated strategy through belonging to a specific } \\
\text { sustainability index? AND Does the company monitor its integrated strategy } \\
\text { through conducting external audits on its reporting? (Asset } 4 \text { mnemonic } \\
\text { CGVSD03S) }\end{array}$ \\
\hline $\begin{array}{l}\text { Score - Vision and } \\
\text { Strategy/Improvements }\end{array}$ & $\begin{array}{l}\text { Does the company set specific objectives to be achieved on the integrated } \\
\text { strategy? (Asset } 4 \text { mnemonic CGVSD04S) }\end{array}$ \\
\hline $\begin{array}{l}\text { Score - Vision and } \\
\text { Strategy/Challenges and } \\
\text { Opportunities }\end{array}$ & $\begin{array}{l}\text { Does the company report about the challenges or opportunities linked to the } \\
\text { integration of financial and extra-financial issues? (Asset } 4 \text { mnemonic } \\
\text { CGVSO01S) }\end{array}$ \\
\hline $\begin{array}{l}\text { Score - Vision and } \\
\text { Strategy/Integrated Strategy }\end{array}$ & $\begin{array}{l}\text { Does the company integrate financial and extra-financial factors in the } \\
\text { management discussion and analysis section of the annual report? (Asset } 4 \\
\text { mnemonic CGVSO02S) }\end{array}$ \\
\hline $\begin{array}{l}\text { Score - Vision and } \\
\text { Strategy/Global Compact } \\
\text { Signatory }\end{array}$ & $\begin{array}{l}\text { Is the company a signatory of the Global Compact? (Asset } 4 \text { mnemonic } \\
\text { CGVSO03S) }\end{array}$ \\
\hline $\begin{array}{l}\text { Score - Vision and } \\
\text { Strategy/Stakeholder } \\
\text { Engagement }\end{array}$ & $\begin{array}{l}\text { Does the company explain how it engages with its stakeholders? (Asset4 } \\
\text { mnemonic CGVSO04S) }\end{array}$ \\
\hline $\begin{array}{l}\text { Score - Vision and } \\
\text { Strategy/Transparency }\end{array}$ & $\begin{array}{l}\text { Does the company publish a separate CSR/H\&S/Sustainability report or publish a } \\
\text { section in its annual report on CSR/H\&S/Sustainability? (Asset } 4 \text { mnemonic } \\
\text { CGVSO05S) }\end{array}$ \\
\hline $\begin{array}{l}\text { Score - Vision and Strategy/GRI } \\
\text { Report }\end{array}$ & $\begin{array}{l}\text { Is the company's CSR report published in accordance with the GRI guidelines? } \\
\text { (Asset } 4 \text { mnemonic CGVSO06S) }\end{array}$ \\
\hline $\begin{array}{l}\text { Score - Vision and } \\
\text { Strategy/Global Reporting }\end{array}$ & $\begin{array}{l}\text { Does the company's extra-financial report take into account of the global } \\
\text { activities of the company? (Asset } 4 \text { mnemonic CGVSO07S) }\end{array}$ \\
\hline $\begin{array}{l}\text { Score - Vision and } \\
\text { Strategy/CSR Reporting } \\
\text { Auditor }\end{array}$ & $\begin{array}{l}\text { Does the company have an external auditor of its CSR/H\&S/Sustainability } \\
\text { report? (Asset } 4 \text { mnemonic CGVSO08S) }\end{array}$ \\
\hline
\end{tabular}

Notes: We identify companies' level of integration based on the variable Asset4 mnemonic CGVS collected from Thomson Reuters Asset4. It is obtained from 12 scores which represent various aspects of implementation of a firm's overall integration strategy. This table reports labels and descriptions of the overall score (CGVS) used as a measure of integrated thinking and reporting (ITR_SCORE), followed by its components (12 score variables). 